\title{
Changes in Bacterial and Fungal Soil Communities in Long-Term Organic Cropping Systems
}

\author{
Jessica Cuartero ${ }^{1, *(\odot)}$, Onurcan Özbolat ${ }^{2}$, Virginia Sánchez-Navarro ${ }^{3}$, Marcos Egea-Cortines $\left.^{2}{ }^{(}\right)$, Raúl Zornoza $^{3}{ }^{(D)}$,

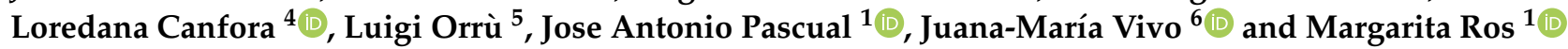 \\ 1 Centre of Edaphology and Applied Biology of the Segura (CEBAS-CSIC), University Campus of Espinardo, \\ 30100 Murcia, Spain; jpascual@cebas.csic.es (J.A.P.); margaros@cebas.csic.es (M.R.) \\ 2 Institute of Plant Biotechnology, Technical University of Cartagena, Plaza del Hospital s/n, \\ 30202 Cartagena, Spain; onurcan.ozbolat@edu.upct.es (O.Ö.); marcos.egea@upct.es (M.E.-C.) \\ 3 Department of Agricultural Science, Universidad Politécnica de Cartagena, Paseo Alfonso XIII 48, \\ 30203 Cartagena, Spain; virginia.sanchez@upct.es (V.S.-N.); raul.zornoza@upct.es (R.Z.) \\ 4 Research Centre for Agriculture \& Environment (AA), Council for Agricultural Research and \\ Economics (CREA), Via della Navicella 2-4, 00184 Roma, Italy; loredana.canfora@crea.gov.it \\ 5 Council for Agricultural Research and Economics (CREA) Research Centre for Genomics and Bioinformatics, \\ Via S. Protaso 302, 29017 Fiorenzuola d'Arda, Italy; luigi.orru@crea.gov.it \\ 6 Department of Statistics and Operations Research, University of Murcia, CMN \& IMIB-Arrixaca, \\ 30100 Murcia, Spain; jmvivomo@um.es \\ * Correspondence: jcuartero@cebas.csic.es; Tel.: +39-968-39-62-00
}

check for updates

Citation: Cuartero, J.; Özbolat, O.; Sánchez-Navarro, V.; Egea-Cortines, M.; Zornoza, R.; Canfora, L.; Orrù, L.; Pascual, J.A.; Vivo, J.-M.; Ros, M. Changes in Bacterial and Fungal Soil Communities in Long-Term Organic Cropping Systems. Agriculture 2021, 11, 445. https://doi.org/10.3390/ agriculture11050445

Academic Editor: Claudio Marzadori

Received: 13 April 2021

Accepted: 13 May 2021

Published: 15 May 2021

Publisher's Note: MDPI stays neutral with regard to jurisdictional claims in published maps and institutional affiliations.

Copyright: (c) 2021 by the authors. Licensee MDPI, Basel, Switzerland. This article is an open access article distributed under the terms and conditions of the Creative Commons Attribution (CC BY) license (https:// creativecommons.org/licenses/by/ $4.0 /)$.

\begin{abstract}
Long-term organic farming aims to reduce synthetic fertilizer and pesticide use in order to sustainably produce and improve soil quality. To do this, there is a need for more information about the soil microbial community, which plays a key role in a sustainable agriculture. In this paper, we assessed the long-term effects of two organic and one conventional cropping systems on the soil microbial community structure using high-throughput sequencing analysis, as well as the link between these communities and the changes in the soil properties and crop yield. The results showed that the crop yield was similar among the three cropping systems. The microbial community changed according to cropping system. Organic cultivation with manure compost and compost tea (Org_C) showed a change in the bacterial community associated with an improved soil carbon and nutrient content. A linear discriminant analysis effect size showed different bacteria and fungi as key microorganisms for each of the three different cropping systems, for conventional systems (Conv), different microorganisms such as Nesterenkonia, Galbibacter, Gramella, Limnobacter, Pseudoalteromonas, Pantoe, and Sporobolomyces were associated with pesticides, while for Org_C and organic cultivation with manure (Org_M), other types of microorganisms were associated with organic amendments with different functions, which, in some cases, reduce soil borne pathogens. However, further investigations such as functional approaches or network analyses are need to better understand the mechanisms behind this behavior.
\end{abstract}

Keywords: compost; high-throughput sequencing; sheep manure; soil properties; crop yield; organic farming; microbial community structure

\section{Introduction}

Currently, one third of agricultural soils worldwide are moderately or highly degraded, thus affecting production [1]. Chemical fertilizers, pesticides, and herbicides are commonly used to maintain soil fertility and crop production in conventional farming [2], and this has generated an increase in greenhouse gas emissions and soil degradation, as well as a decrease in soil biodiversity [3]. In this context, organic farming is of growing interest. Organic farming includes the use of organic fertilizers, such as compost, manure, or green manure, and places an emphasis on techniques like rotation with companion plants or intercropping, and pest and disease control by natural methods, avoiding synthetic 
chemical compounds, preserving the environment, and providing human beings with high-nutrition crops that are free of chemicals [4]. In the European Union, almost 180 million hectares are dedicated to agriculture, of which around 13 million were dedicated to organic farming in 2018. Spain is the EU country with the largest area devoted to organic farming [5], with more than 2.2 million hectares, accounting for $16.7 \%$ of the total farmed land in the country.

Some studies have reported that organic crop production is between $10-30 \%$ lower than in conventional farming, with differences depending on the crop species, growing conditions, and management practices [6]. Nonetheless, recent studies have highlighted that long-term organic management can contribute crop yields similar to those found in conventional farming, once the system has been stabilized, after initial years with a reduction in crop yields [7,8]. For this reason, more information about the relative variability of organic systems compared with conventional ones is necessary in order to reinforce the use of organic farming.

Soil microorganisms play an important role in ecosystem processes, such as carbon cycling, decomposition, nutrient cycling, and soil aggregate formation [9], and determining this relationship is very complex [10]. Understanding how these microorganisms respond to organic matter, inorganic fertilizers, and soil management can help farmers to improve soil health for crop production [10-12]. Approaches like high-throughput analysis of bacterial and fungal communities can show taxonomic shifts, shaping the patterns of the ecological interactions that regulate the structure, function, and resilience of soil microbial communities under organic farming compared with conventional farming.

However, there are no conclusive results regarding this. Some studies have reported that after long-term organic farming, the microbial diversity, soil sustainability, and beneficial microorganisms involved in plant health were higher than in conventional farming [13-15]. However, Bell et al. [16] and Krishnaraj and Sabale [17] found that organic cropping systems showed no significant differences, or showed an even lower microbial diversity, compared with conventional cropping. So, we found a gap of knowledge that needs more results from long-term field experiments, such as the one presented here, to know how soil microbial communities change across different organic farming types.

The aim of this paper was to investigate the potential differences between two organic systems (organic cultivation with manure compost and compost tea (Org_C) and organic cultivation with manure (Org_M) with a conventional system (Conv). For this purpose, in the three studied agricultural systems, the soil bacterial and fungal communities were studied through high-throughput sequencing analysis, focusing and studying their relationship using physico-chemical soil properties and crop production. We hypothesized that (a) organic systems would not have significant differences on crop production compared with the conventional system, as once an organic system is stabilized, soil functionality is improved, contributing to a high nutrient availability and soil health; (b) both organic systems (Org_C and Org_M) would promote changes in the microbial structure and abundance compared with the conventional system; and (c) that changes promoted by cropping system can be either beneficial or detrimental to plants, thus influencing soil stability and quality.

\section{Materials and Methods}

\subsection{Experiment Description and Sampling}

The study site was located in the Campo de Cartagena, an agrarian region of southeastern Spain. The soil was a Haplic Calcisol (Loamic, Hypercalcic) IUSS [18]. The area has a mean annual temperature of $17.5^{\circ} \mathrm{C}$, a mean annual precipitation of $280 \mathrm{~mm}$, and an annual potential evapotranspiration of $1300 \mathrm{~mm}$. The site has been under vegetable cultivation since the early 1990s, using drip fertigation, rotation, and multiple cropping. Three cropping systems were selected for this study, where the following five random plots ( $1 \mathrm{ha}$ ) were set up for each cropping system: (1) a conventional system using a yearly addition of sheep manure as an organic amendment, inorganic fertilizer for fertigation, and 
pesticides (Conv); (2) an organic system using a yearly addition of compost, amino acids to provide $\mathrm{N}$, compost tea to provide organic compounds and nutrients for fertigation, no pesticides, and the use of cover crops of oat (Avena sativa) and vetch (Vicia sativa) between cropping seasons (Org_C); and (3) an organic system using a yearly addition of sheep manure, amino acids as fertigation to provide $\mathrm{N}$, and no pesticides (Org_M). The three cropping systems are described in detail in Table 1. One composite sample derived from ten subsamples ( $0-10 \mathrm{~cm}$ depth) was collected using an auger from each plot in February 2018 after the harvest of a leaf cabbage crop (Brassica olearacea var. sabellica).

Table 1. Management characteristics of the three cropping systems.

\begin{tabular}{cccc}
\hline Cultivation System & Conv & Org_C & Org_M \\
\hline Geographical coordinates & $37^{\circ} 48^{\prime} 18.5^{\prime \prime} \mathrm{N}, 0^{\circ} 51^{\prime} 49.2^{\prime \prime} \mathrm{W}$ & $37^{\circ} 51^{\prime} 39.3^{\prime \prime} \mathrm{N}, 0^{\circ} 54^{\prime} 03.3^{\prime \prime} \mathrm{W}$ & $37^{\circ} 49^{\prime} 30.2^{\prime \prime} \mathrm{N}, 0^{\circ} 52^{\prime} 28.4^{\prime \prime} \mathrm{W}$ \\
\hline Crop & & Brassica oleracea var. sabellica & \\
$2017-2018$ season & &
\end{tabular}

\begin{tabular}{cc}
\hline Harvest & Manual on 20-25 February 2018. Crop residues were incorporated in the soil \\
\hline $\begin{array}{c}\text { Crops grown in previous } \\
\text { years }\end{array}$ & Apium graveolens/Cucumils melo $(2016 / 2017)$ \\
& Apium graveolens/Cucumils melo $(2014 / 2015)$ \\
Brassica oleracea var. Italica/Capsicum annum $(2013 / 2014)$ \\
Foeniculum vulgare/Cucurbita moschata $(2012 / 2013)$
\end{tabular}

\begin{tabular}{|c|c|c|c|}
\hline $\begin{array}{l}\text { Organic amendments } \\
\text { (amount per year) }\end{array}$ & $15,000 \mathrm{~kg} \mathrm{ha}^{-1}$ sheep manure & $\begin{array}{l}10,000 \mathrm{~kg} \mathrm{ha}^{-1} \text { sheep } \\
\text { compost; compost tea * }\end{array}$ & $15,000 \mathrm{~kg} \mathrm{ha}^{-1}$ sheep \\
\hline
\end{tabular}
$15 \mathrm{~kg} \mathrm{ha}^{-1}$ ENTEC solub 21

Fertilizers (ammonium sulfate with inhibition of (amount per year) nitrification); $10 \mathrm{~L} \mathrm{ha}^{-1}$ phosphoric acid; $15 \mathrm{~kg} \mathrm{ha}^{-1}$ calcium nitrate;

$10 \mathrm{~L} \mathrm{ha}^{-1}$ EcoZen NPK 2-2-7 (aminoacids); $10 \mathrm{~L} \mathrm{ha}^{-1}$ Sunfol veg agri $12 \%$ (aminoacids) $10 \mathrm{~L} \mathrm{ha}^{-1}$ nitric acid
Linuron; Indoxacarb 30\%; Cypermethrin;Lambda cihalotrin $10 \%$; Imidacloprid 20\%; Spinosad; Pesticides $\quad$ Azadirachtin 3.2\%; Emamectin 0.85\%; Clortalonil 50\%; Difenoconazol 25\%; Azoxystrobin 2.5\%; Propamocarb $52 \%$; Ciflufenamid

Conv—conventional system; Org_C_-organic cultivation with sheep manure compost and compost tea; Org_M-organic cultivation with sheep manure. * The compost tea was made on each farm by steeping mature compost in water for $24 \mathrm{~h}$.

The characteristics of the sheep manure, compost, and tea compost are shown in Table S1. Sheep manure and its compost were chosen because of their proximity to the experimental plot, thereby reducing the environmental and economic impact of their transportation to the experimental site. The amount of compost added annually in the Org_C treatment before each crop cycle was lower than the amount of manure added before each cycle for the Conv or Org_M treatments; because soluble organic compounds were continuously added during the crop cycle by fertigation with the compost tea in Org_C, the organic matter was not added all at once but rather over an extended period of time (Table 1).

Soil samples were separated into two aliquots. One was kept at ambient temperature for physicochemical analyses and the other was stored in a cool box with ice for a molecular analysis. The samples were taken to the lab immediately. The soil for the molecular analysis was sieved at $<2 \mathrm{~mm}$ and stored at $-20^{\circ} \mathrm{C}$. The soil was air-dried for one week for the physicochemical analyses and sieved at $<2 \mathrm{~mm}$. The soil cores were taken using steel cylinders to determine the soil bulk density [19]. 


\subsection{Soil Properties and Crop Yield}

The actual field soil moisture content (FMa) was gravimetrically determined according to De Angelis [20]. The cation exchange capacity (CEC) and exchangeable $\mathrm{Ca}^{2+}, \mathrm{Mg}^{2+}$, $\mathrm{K}^{+}$, and $\mathrm{Na}^{+}$were determined using $\mathrm{BaCl} 2$ as the exchangeable cation, following ISO (international standard method) 13536 [21]. The soil water content at wilting point (SWW) and soil water content at field capacity (SWFC) were calculated using the retention curve method [22], in which moist samples were dried by raising the air pressure in an extractor with a porous ceramic plate [23]. The soil $\mathrm{pH}$ and electrical conductivity (EC) were measured in deionized water (1:5 w/v). The total organic carbon (TOC), inorganic carbon (IC), and total nitrogen (TN) were determined using an elemental CHNS-O analyzer (EA1108, Carlo Erba, Barcelona, Spain), and the $\mathrm{CaCO}_{3}$ content was calculated from the IC. The particulate organic carbon (POC), defined as a fresh or decomposing organic material, was measured according to Cambardella and Elliot [24]; in long-term experiments, POC can be used as an early indicator of soil organic matter (SOM), corresponding to the functional pool of organic matter stabilized by specific mechanisms [25]. Soil $\mathrm{NH}_{4}{ }^{+}$was extracted with $2 \mathrm{M} \mathrm{KCl}$ in a 1:10 soil/extractant ratio, and was calorimetrically measured [26,27]. Soil $\mathrm{NO}_{3}{ }^{-}$was extracted with deionized water in a 1:10 soil:extractant ratio and was measured by ion chromatography (Metrohm 861). The available P (P) was measured using the Olsen method [28]. The available $\mathrm{Fe},(\mathrm{Fe}) \mathrm{Mn}(\mathrm{Mn}), \mathrm{Cu}(\mathrm{Cu})$, and $\mathrm{Zn}(\mathrm{Zn})$ were extracted by chelation using DTPA $(1: 2 w / v)[29,30]$. The available B (B) was extracted with deionized water $(1: 5 w / v)$ at $50{ }^{\circ} \mathrm{C}$ [31]. The available nutrients were measured using ICP-MS (7500CE, Agilent, Santa Clara, CA, USA). The total pesticides were determined with the QuEChERS method [32], according to which, $5 \mathrm{~g}$ of a homogenized sample was extracted with $10 \mathrm{~mL}$ acetonitrile containing $1 \%$ acetic acid. The pesticides were analyzed through liquid chromatography triple quadrupole mass spectrometry (LC-MS/MS; TQS MS linked to a Waters Acquity UPLC system, Waters Corporation, Milford, MA, USA) and gas chromatography triple quadrupole mass spectrometry (GC-MS/MS; Agilent 7890B GC coupled to an Agilent 7010B MS system, Santa Clara, CA, USA).

The leaf cabbage yield $\left(\mathrm{kg} \mathrm{ha}^{-1}\right)$ was calculated based on the weight of all marketable plants (suitable for sale according to size) in each plot.

\subsection{DNA Extraction, $P C R$, and Sequencing}

Soil DNA was extracted from $1 \mathrm{~g}$ of soil (wet weight) using the DNeasy Power Soil Kit (Qiagen, Hilden, Germany), following the manufacture's protocol, with the modifications described by Taskin et al. [33]. The quantity and quality of DNA extracts were quantified using a Qubit 3.0 Fluorometer (Invitrogen, Thermo Fisher Scientific, Waltham, MA, USA) and a NanoDrop 2000 fluorospectrometer (Thermo Fisher Scientific, Waltham, MA, USA).

The bacterial community was determined through the next-generation-sequencing of bacterial 16S hypervariable regions using the Ion Torrent ${ }^{\mathrm{TM}}$ Personal Genome Machine ${ }^{\mathrm{TM}}$ (PGM, London, UK) System. Bacterial $16 \mathrm{~S}$ regions were amplified using an Ion $16 \mathrm{~S}^{\mathrm{TM}}$ Metagenomics Kit (Thermo Fisher Scientific, Waltham, MA, USA) with two different degenerate primer sets to amplify regions V2-4-8 and V3-6, V7-9. The amplified $16 \mathrm{~S}$ amplicons were then processed using an Ion Xpress ${ }^{\mathrm{TM}}$ Plus Fragment Library Kit in combination with an Ion Xpress ${ }^{\mathrm{TM}}$ Barcode Adapter 1-96 Kit (Thermo Fisher Scientific, Waltham, MA, USA). All of the purification processes between incubation and the amplification reactions of library preparation were processed using DynaMag ${ }^{\mathrm{TM}}-2$ magnetic racks (Thermo Fisher Scientific, Waltham, MA, USA) and an AMPure XP Purification Kit (Beckman Coulter, Brea, CA, USA). Library preparation and barcoding were followed by the determination of the size and concentration of the final libraries using an Agilent 2100 Bioanalyzer system and the Agilent High Sensitivity DNA kit (Agilent, Santa Clara, CA). Sequencing templates were prepared using an Ion One Touch 2 System and an Ion PGM $^{\mathrm{TM}} \mathrm{Hi}-\mathrm{Q}^{\mathrm{TM}}$ View OT2 Kit (Thermo Fisher Scientific, Waltham, MA, USA). The sequencing reaction was performed using Ion Torrent PGM (Thermo Fisher Scientific, Waltham, MA, USA) with an Ion PGMTM Hi-QTM View Sequencing Kit (Thermo Fisher Scientific, Waltham, MA, USA). 
Fungal libraries were prepared using a protocol based on the method proposed by Smith and Peay [34], with some modifications. Sequencing libraries were produced by PCR amplification using the primer pairs ITS1f-ITS2 tailed with the Illumina adapters (Illumina, San Diego, CA, USA). The reverse primers were barcoded using the 12-base Golay barcodes [35]. DNA extraction had a minimum concentration of $10 \mathrm{ng} / \mu \mathrm{L}$ with a least $200 \mathrm{ng}$ provided. The PCR amplifications were conducted in a final volume of $30 \mu \mathrm{L}$ containing $3 \mu \mathrm{L}$ of buffer $10 \times, 0.7 \mu \mathrm{L}$ of each primer $(10 \mathrm{mM}), 0.9 \mu \mathrm{L}$ of $50 \mathrm{mM} \mathrm{MgSO}_{4}$, $0.6 \mu \mathrm{L}$ of $10 \mathrm{mM}$ dNTP, $2 \mu \mathrm{L}$ of template DNA $(10 \mathrm{ng} / \mathrm{mL}), 21.98 \mu \mathrm{L}$ of PCR-grade water, and $0.12 \mu \mathrm{L}$ of Invitrogen Platinum Taq DNA polymerase High Fidelity (Cat $\mathrm{N}^{\circ} 11304-011$ ), using the following conditions: $3 \mathrm{~min}$ initial denaturation at $95^{\circ} \mathrm{C}$, followed by 35 cycles of denaturation at $95{ }^{\circ} \mathrm{C}$ for $45 \mathrm{~s}$, annealing at $50{ }^{\circ} \mathrm{C}$ for $1 \mathrm{~min}$, extension at $72{ }^{\circ} \mathrm{C}$ for $1 \mathrm{~min}$, and a final extension at $72{ }^{\circ} \mathrm{C}$ for $10 \mathrm{~min}$. The PCR products were cleaned up from primers using Agencourt AMPure XP beads (Beckman Coulter, Indianapolis, IN, USA), following the manufacturer's instructions. The PCR products were checked on a Bioanalyzer DNA 1000 kit (Agilent, Santa Clara, CA, USA) to verify the size. Amplicons were quantified with Qubit using the dsDNA HS Assay kit (Thermo Fisher Scientific, Waltham, MA, USA). Amplicon libraries were sequenced on the Illumina MiSeq machine (Illumina, San Diego, CA, USA), together with a 10\% PhiX (Illumina, San Diego, CA, USA), control library to generate 300 bp paired end reads.

\subsection{Sequencing Data Processing}

For bacterial raw sequences, the barcodes and primers were trimmed according to the BaseCaller software (ThermoFisher, Waltham, MA, USA). The sequences were denoised with ACACIA v 1.53 [36], and low quality sequences were discarded using the Quantitative Insights into Microbial Ecology (QIIME) pipeline v 1.9.1 [37] from the Microbiome Helper Virtual Box v 2.3 [38]. Briefly, bacterial sequences with a $Q<25$ were removed and the retained sequences were then assigned to Operational Taxonomic Units (OTUs) based on $97 \%$ similarity with the SILVA reference database 128 after filtering chimeras using VSEARCH v 2.4.3 [39] with the ribosomal database project (RDP_trainset16_022016.fa) [40]. Low confidence OTUs were removed. To correct the sampling effect, the number of sequences was established at 19,840.

Fungal raw reads were trimmed for adapters and low quality reads using the Trimmomatic v 0.38 program [41], setting the quality cutoff to 20 in 24 bp sliding windows. Trimmed reads were assembled using the paired-end read merger (PEAR) program v 0.9.10 [42]. Chimeras were removed using VSEARCH v 2.4.3 from the QIIME pipeline v 1.9.1 using the UCHIME reference dataset (uchime_sh_refs_dynamic_original_985_03.07.2014.fasta). OTUs were assigned based on 97\% similarity using the open reference OTU picking protocol implemented in the QIIME toolkit v 1.9.1. Taxonomy was assigned using the UNITE database (sh_taxonomy_qiime_ver7_dynamic_20.11.2016.txt) [43]. Low abundance OTUs (OTUs with less than three reads) were removed.

The sequences were uploaded to the European Nucleotide Archive (ENA) with the study accession code PRJEB38121.

\subsection{Fungal Pathogen Detection by $q P C R$}

Real-time PCR was performed to quantify the number of ITS copies in the soil DNA using a 7500 fast real-time PCR system (Applied Biosystems, Foster City, CA, USA). The reaction mixtures $(15 \mu \mathrm{L})$ contained a final concentration of $1 \times$ TaqMan Universal Master Mix II no UNG (Applied Biosystems, Foster City, CA, USA), $0.3 \mu \mathrm{m}$ of each primer, $0.1 \mu \mathrm{m}$ of TaqMan probe, $0.1 \mathrm{mg} \mathrm{mL}^{-1}$ of bovine serum albumin (BSA), $3 \mu \mathrm{L}$ of DNA template, and nuclease-free water. The PCR program consisted of an initial denaturation step at $95^{\circ} \mathrm{C}$ for $10 \mathrm{~min}$, followed by 40 cycles at $95^{\circ} \mathrm{C}$ for $10 \mathrm{~s}$, and at $60^{\circ} \mathrm{C}$ for $40 \mathrm{~s}$, as well as a final step at $50^{\circ} \mathrm{C}$ for $2 \mathrm{~min}$. Three real-time PCRs were carried out for each DNA sample. The amplification results were analyzed with 7500 Fast Real-time PCR software v.2.0 (Applied Biosystems, Foster City, CA, USA). Fungal pathogen detection and quantification 
were performed using the Vegalert qPCR quantitative kits for curcubits (Alternaria spp. (ALT), Rhizoctonia solani (RSO), and Fusarium oxysporum (FOX); Microgaia Biotech S.L, Murcia, Spain).

\subsection{Statistical Analysis}

The normality and homogeneity of variance assumptions were evaluated using Shapiro-Wilk and Levene's tests. For a mean comparison between the cropping systems, one-way analysis of variance (ANOVA) was performed, followed by Tukey's honestly significant difference (HSD) post hoc test if the effects were significant. Where conditions for homoscedasticity were not met, we used Welch's test followed by the "pairwise.t.test" function, with P adjusted by the Bonferroni-Holm method for multiple comparisons [44]. Non-parametric Kruskal-Wallis tests were used when normality assumptions were not fulfilled. When such test statistics were significant, Kruskal-Wallis multiple comparison Z-value tests were performed using the "dunnTest" function, with P adjusted by the Benjamini-Hochberg method in the FSA package v 0.8 .3 [45]. Principal component analysis (PCA) was conducted as an unsupervised learning dimension reduction technique to visualize the cohesion and separation of the three cultivation systems. From the outcomes reported by the FactoMineR package v 1.42 [46], a PCA biplot was generated using the factoextra package $v$ 1.0.5 [47] to assess the contribution of each parameter to the component loading.

For both bacterial and fungal communities, the rarefaction curves and the Chao1 and Shannon diversity indexes were calculated using the $\mathrm{R} v$ 1.1.453 packages of iNEXT $\mathrm{v}$ 2.0.19 [48] and vegan [49]. The effects of the cultivation systems on such indexes were evaluated by one-way ANOVA. Significant differences were tested by Tukey's HSD test. Violin plots were generated to show the distributional shape of each index across all soil samples grouped according to the cropping system.

A similarity percentages (SIMPER) analysis was conducted using the "simper" function of the vegan package $\mathrm{v} 2.5 .6$ to identify the parameters that most contributed to the pairwise differences between the cropping systems at a phylum level. PERMANOVA was conducted to test the differences among the cropping systems if the homogeneity of variance assumption was met, and an analysis of similarities (ANOSIM) was carried out if not.

A linear discriminant analysis (LDA) effect size (LEfSe; Galaxy community hub https:/ / huttenhower.sph.harvard.edu/galaxy/, accessed on 20 November 2020) under the default parameters was implemented to identify differentially abundant groups among the three cropping systems [50,51].

In order to visualize and test whether the microbial community structures (OTUs) of the three cropping systems were distinct, a principal coordinate analysis (PCoA) and permutational multivariate analysis of variance (PERMANOVA) were conducted based on the Bray-Curtis distance, using the "betadisper" and "adonis" functions in the vegan package with 999 permutations. The soil microbial community composition was ordinated applying non-metric multidimensional scaling (NMDS) with the Bray-Curtis dissimilarity matrices using the "metaMDS" function in the vegan package. During the NMDS analysis, the relationships between the soil properties and soil microbial community were assessed using the "envfit" function available in the vegan package.

\section{Results}

\subsection{Effects of Different Cropping Systems on Soil Physico-Chemical Properties, Soil Pathogens,} and Crop Yield

The univariate analysis showed that Org_M had a significantly higher $\mathrm{pH}(8.70)$ than Conv (8.39), with no significant differences with Org_C (8.47; Table 2). The TOC, TN, and $\mathrm{NH}_{4}{ }^{+}$contents were significantly higher in Org_C than in the other two systems, while the $\mathrm{NO}_{3}{ }^{-}$content was significantly higher in Conv than in Org_C. POC showed significantly higher values in Org_M than in Org_C. Fe, Mn, and B showed significantly higher values 
in Org_C and Conv than in Org_M. Mg was significantly higher in Org_C than in Org_M, and $\mathrm{K}$ was significantly higher in Org_C than in Conv (Table 2). The Conv system showed the significantly highest amount of total pesticides (TP).

Table 2. Effects of the three cropping systems on soil properties.

\begin{tabular}{|c|c|c|c|c|c|}
\hline \multirow{2}{*}{ Soil Properties } & \multicolumn{3}{|c|}{ Cropping System } & \multirow{2}{*}{ Anova } & \multirow{2}{*}{ Kruskal-Wallis } \\
\hline & Conv & Org_C & Org_M & & \\
\hline $\mathrm{pH}$ & $8.39 \pm 0.17 b$ & $8.47 \pm 0.14 \mathrm{ab}$ & $8.70 \pm 0.10 \mathrm{a}$ & * & - \\
\hline $\mathrm{EC}\left(\mathrm{dS} \mathrm{m}^{-1}\right)$ & $0.54 \pm 0.15$ & $0.52 \pm 0.13$ & $0.38 \pm 0.04$ & - & ns \\
\hline TOC $\left(\mathrm{g} \mathrm{kg}^{-1}\right)$ & $11.49 \pm 0.28 \mathrm{ab}$ & $15.64 \pm 3.37 \mathrm{a}$ & $9.01 \pm 3.49 b$ & $* *$ & - \\
\hline $\mathrm{TN}\left(\mathrm{g} \mathrm{kg}^{-1}\right)$ & $1.13 \pm 0.19 \mathrm{~b}$ & $1.59 \pm 0.34 \mathrm{a}$ & $0.93 \pm 0.24 b$ & $* *$ & - \\
\hline POC $\left(\mathrm{g} \mathrm{kg}^{-1}\right)$ & $2.67 \pm 0.72 \mathrm{ab}$ & $2.20 \pm 0.55 b$ & $4.03 \pm 1.40 \mathrm{a}$ & * & - \\
\hline $\mathrm{NH}_{4}{ }^{+}\left(\mathrm{mg} \mathrm{kg}^{-1}\right)$ & $0.10 \pm 0.23 \mathrm{~b}$ & $1.33 \pm 0.15 b$ & $0.00 \pm 0.00 \mathrm{a}$ & - & $* *$ \\
\hline $\mathrm{NO}_{3}-\left(\mathrm{mg} \mathrm{kg}^{-1}\right)$ & $53.04 \pm 28.27 \mathrm{a}$ & $11.86 \pm 7.10 \mathrm{ab}$ & $27.00 \pm 13.57 \mathrm{~b}$ & - & * \\
\hline Bulk density $\left(\mathrm{kg} \mathrm{dm}^{-3}\right)$ & $1.24 \pm 0.06$ & $1.27 \pm 0.07$ & $1.34 \pm 0.09$ & ns & - \\
\hline SWW $\left(\mathrm{cm}^{3} \mathrm{~cm}^{-3}\right)$ & $0.12 \pm 0.01$ & $0.12 \pm 0.02$ & $0.12 \pm 0.03$ & ns & - \\
\hline $\operatorname{SWFC}\left(\mathrm{cm}^{3} \mathrm{~cm}^{-3}\right)$ & $0.22 \pm 0.01$ & $0.25 \pm 0.03$ & $0.22 \pm 0.02$ & ns & - \\
\hline $\mathrm{CEC}\left(\mathrm{cmol} \mathrm{kg}^{-1}\right)$ & $14.82 \pm 0.86$ & $17.47 \pm 4.13$ & $12.76 \pm 2.20$ & - & ns \\
\hline $\mathrm{CaCO}_{3}(\%)$ & $44.65 \pm 2.71$ & $45.54 \pm 7.57$ & $47.03 \pm 1.92$ & - & ns \\
\hline FMA $\left(\mathrm{cm}^{3} \mathrm{~cm}^{3-1}\right)$ & $0.17 \pm 0.03$ & $0.20 \pm 0.06$ & $0.19 \pm 0.03$ & - & ns \\
\hline $\mathrm{Ca}\left(\mathrm{cmol} \mathrm{kg}^{-1}\right)$ & $8.44 \pm 0.83$ & $10.03 \pm 2.40$ & $7.19 \pm 1.49$ & - & ns \\
\hline $\operatorname{Mg}\left(\mathrm{cmol} \mathrm{kg}^{-1}\right)$ & $3.54 \pm 0.11 \mathrm{ab}$ & $4.39 \pm 1.09 \mathrm{a}$ & $3.13 \pm 0.54 b$ & * & - \\
\hline $\mathrm{K}\left(\mathrm{cmol} \mathrm{kg}^{-1}\right)$ & $0.62 \pm 0.15 \mathrm{~b}$ & $0.85 \pm 0.17 \mathrm{a}$ & $0.78 \pm 0.06 \mathrm{ab}$ & * & - \\
\hline $\mathrm{Na}\left(\mathrm{cmol} \mathrm{kg}^{-1}\right)$ & $2.12 \pm 0.32$ & $2.19 \pm 0.86$ & $1.64 \pm 0.23$ & ns & - \\
\hline $\mathrm{P}\left(\mathrm{mg} \mathrm{kg}^{-1}\right)$ & $20.15 \pm 5.24$ & $14.65 \pm 7.71$ & $14.33 \pm 7.48$ & ns & - \\
\hline $\mathrm{Cu}\left(\mathrm{mg} \mathrm{kg}^{-1}\right)$ & $2.17 \pm 0.74$ & $3.17 \pm 0.81$ & $2.19 \pm 0.75$ & ns & - \\
\hline $\mathrm{Zn}\left(\mathrm{mg} \mathrm{kg}^{-1}\right)$ & $4.75 \pm 2.99$ & $5.46 \pm 1.65$ & $4.48 \pm 0.91$ & ns & - \\
\hline $\mathrm{Fe}\left(\mathrm{mg} \mathrm{kg}^{-1}\right)$ & $6.19 \pm 2.91 \mathrm{a}$ & $6.97 \pm 2.69 b$ & $2.99 \pm 1.24 \mathrm{a}$ & - & * \\
\hline $\mathrm{Mn}\left(\mathrm{mg} \mathrm{kg}^{-1}\right)$ & $9.47 \pm 1.03 \mathrm{a}$ & $7.91 \pm 2.37 \mathrm{a}$ & $4.66 \pm 0.36 \mathrm{~b}$ & $* * *$ & - \\
\hline $\mathrm{B}\left(\mathrm{mg} \mathrm{kg}^{-1}\right)$ & $1.68 \pm 0.11 \mathrm{a}$ & $1.94 \pm 0.28 \mathrm{a}$ & $1.31 \pm 0.17 b$ & $* *$ & - \\
\hline $\mathrm{TP}\left(\mathrm{ng} \mathrm{g}^{-1}\right)$ & $232.00 \pm 146.54 \mathrm{a}$ & $13.36 \pm 9.11 b$ & $6.08 \pm 5.21 b$ & - & $* *$ \\
\hline ALT (log copy ITS g ${ }^{-1}$ soil) & $4.24 \pm 0.32 \mathrm{a}$ & $4.33 \pm 0.49 \mathrm{a}$ & $2.05 \pm 1.88 \mathrm{~b}$ & - & $* *$ \\
\hline RSO (log copy ITS g ${ }^{-1}$ soil) & $0.67 \pm 1.51$ & $2.72 \pm 1.61$ & $2.02 \pm 1.86$ & - & ns \\
\hline FOX (log copy ITS g ${ }^{-1}$ soil) & $3.08 \pm 1.73 \mathrm{a}$ & $3.30 \pm 0.44 \mathrm{a}$ & $0.63 \pm 1.41 \mathrm{ab}$ & - & * \\
\hline
\end{tabular}

EC—electrical conductivity; TOC—-total organic carbon; TN—total nitrogen; POC—particulate organic carbon; SWW—soil wilting point; SWFC—field capacity; CEC—cation exchange capacity; FMA—actual field soil moisture; Available $(\mathrm{Ca}, \mathrm{Mg}, \mathrm{K}, \mathrm{Na}, \mathrm{P}, \mathrm{Cu}, \mathrm{Zn}, \mathrm{Fe}, \mathrm{Mn}$, and B); TP-total pesticides; ALT-Alternaria spp.; RSO-Rhizoctonia solani; FOX-Fusarium oxysporum. Conv—conventional system; Org_C_-organic cultivation with sheep manure compost and compost tea; Org_M—organic cultivation with sheep manure. Values (mean \pm standard deviation $n=5$ ) followed by different lower letters correspond to significant differences between cultivation systems (Tukey's test or pairwise $t$-test by groups); (ns) non-significant differences between cultivation systems. (-) the test does not proceed; significant levels: ${ }^{* * *} p<0.001 ;{ }^{* *} p<0.01 ; * p<0.05$.

The abundance of Alternaria spp. (ALT) was significantly the lowest in Org_M, while Fusarium oxysporum (FOX) was significantly lower in Org_M than in Conv and Org_C; there were no significant differences in Rhizoctonia Solani (RSO) among the cropping systems (Table 2).

The obtained biplot reflected the differences among the three cropping systems (Figure 1). Org_C was associated with TOC, $\mathrm{TN}, \mathrm{B}, \mathrm{Mg}$, and $\mathrm{NH}_{4}{ }^{+}$, contrary to Org_M, which was negatively correlated with POC (Figure 1). The Conv system was positively correlated with the total pesticide content. 


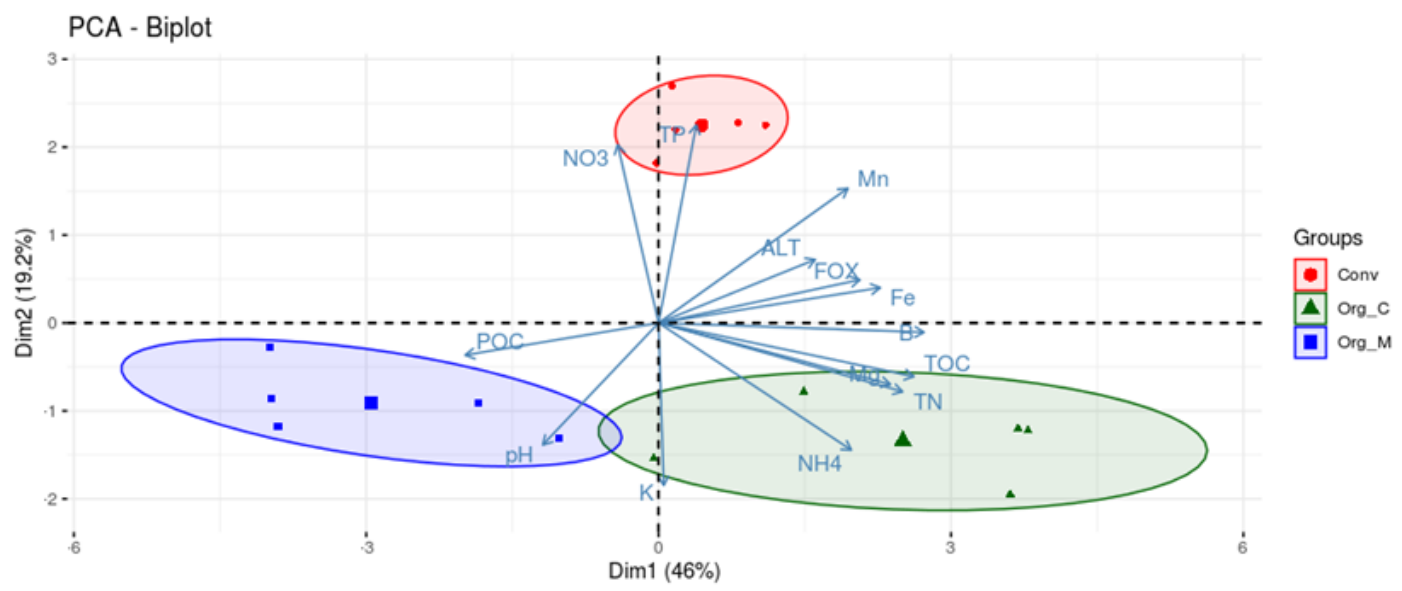

Figure 1. Principal component analysis (PCA) of the soil properties. The two first principal components are shown on the $x$ and $y$-axes, respectively. PCA scores represent soil samples, with colors indicating the corresponding cultivation systems. Ellipses represent 70\% confidence intervals around the barycenters for the samples classified by each cultivation system. TOC — total organic carbon; TN—total nitrogen; POC—particulate organic carbon; Mg—exchangeable Mg; Fe—bioavailable Fe; Mn—bioavailable Mn; B—bioavailable B; TP—total pesticides; ALT—Alternaria spp.; FOX—Fusarium oxisporum; Convconventional system; Org_M-organic cultivation system with sheep manure; Org_C_organic cultivation system with sheep manure compost and compost tea ( $n=5$, per cropping system).

No significant differences were found for the cabbage yield among the three cropping systems (Figure 2).

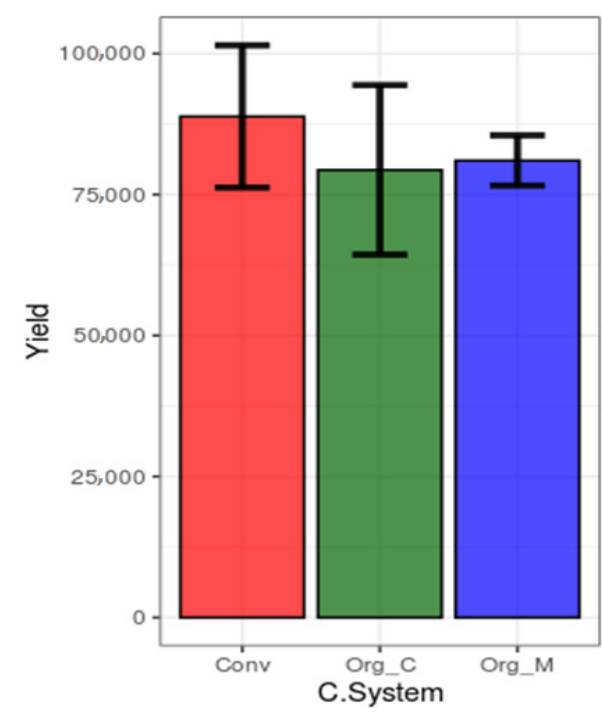

Figure 2. The crop yield $\left(\mathrm{kg} \mathrm{ha}^{-1}\right)$ of the three cropping systems. Error bars represent mean \pm standard deviation (SD; $n=5)$. No significant differences were found among the three cultivation systems (Kruskal-Wallis test, $p>0.05$ ). Conv—conventional system; Org_M-organic cultivation system with sheep manure; Org_C_-organic cultivation system with sheep manure compost and compost tea.

\subsection{Effects of Different Cropping Systems on Soil Microbial Diversity}

A total of 592,250 16S sequences (clustered into 18,533 OTUs) for bacteria and 1,186,964 ITS sequences (clustered into 611 OTUs) for fungi were obtained from all of the soil samples. Rarefaction curves showed a coverage value of $0.84-0.88$ for bacteria and 0.99 for fungi (Figure S1). Different microbial indices were calculated for the microbial communities (Figure 3 and Table S2). The Chao1 index showed no significant differences in the bacterial and fungal communities among the three cropping systems (Figure 3 and Table S2). The 
Shannon index showed no differences for the bacterial community, but did show significant differences for fungi, which had significantly higher values in Conv and Org_M than in Org_C (Figure 3 and Table S2).

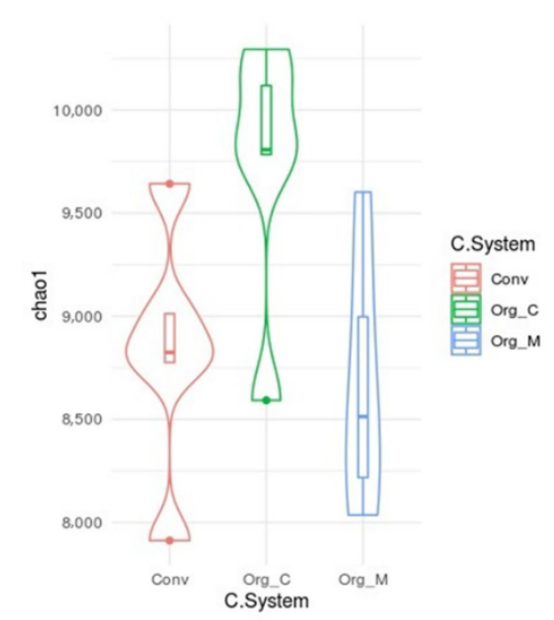

(A)

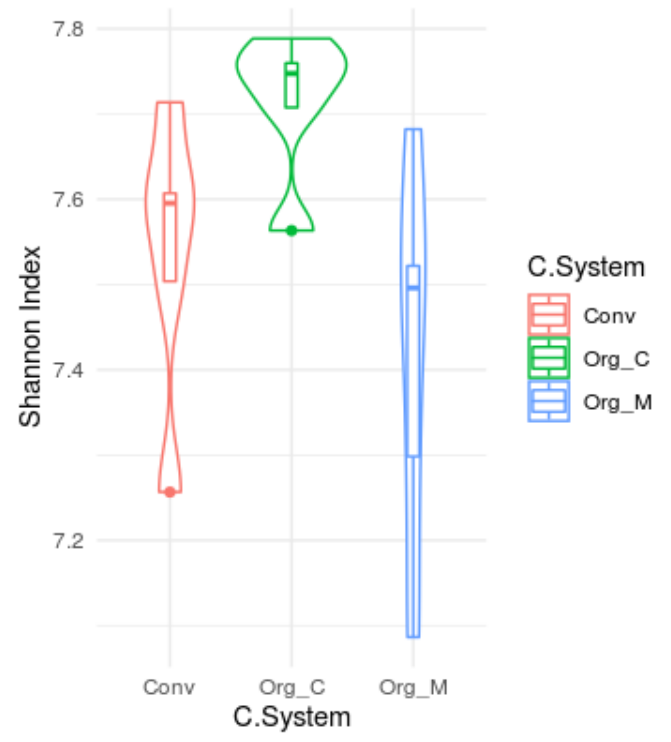

(C)

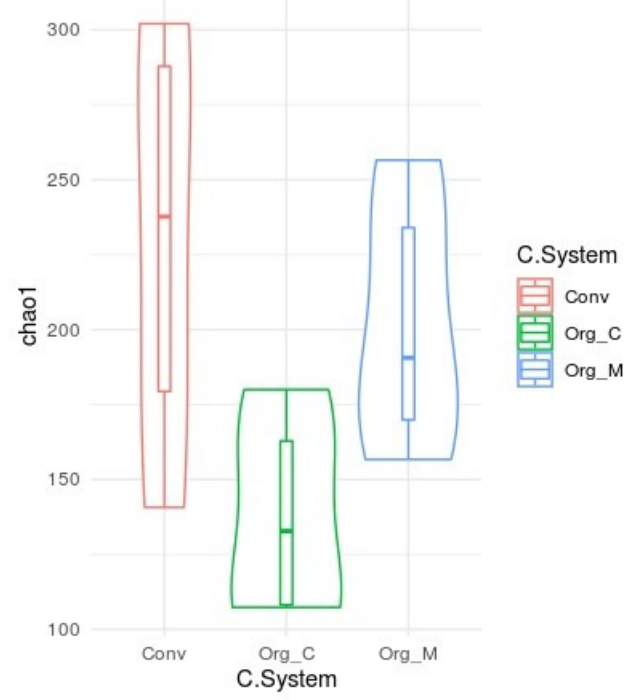

(B)

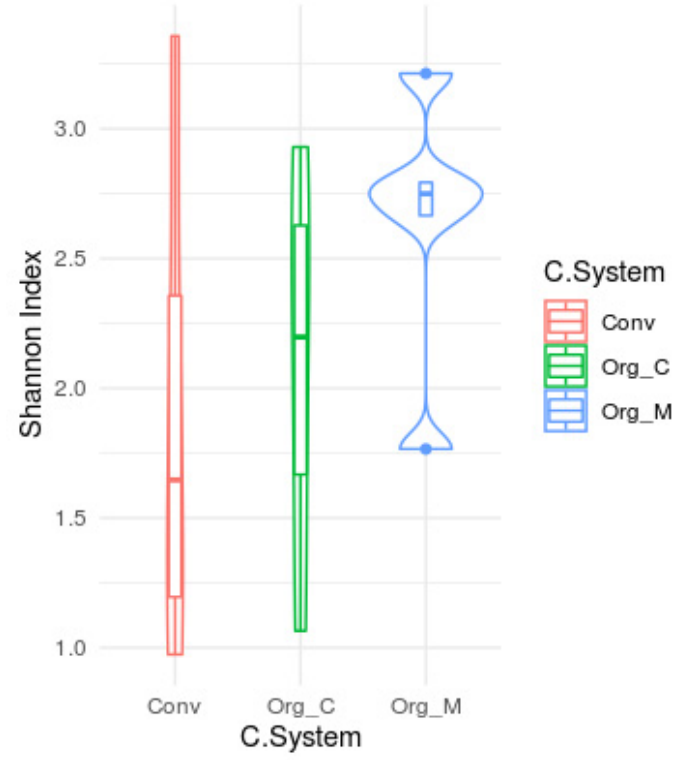

(D)

Figure 3. Violin plots displaying the diversity indexes in the three cultivation systems. The distributional features of the data are depicted by the kernel density trace overlaid on the descriptive statistics (median and whisker range from $25 \%$ to $75 \%$ ) represented by a boxplot. Chao1 for (A) bacterial and (B) fungal communities, and Shannon index for (C) bacterial and fungal (D) communities. Conv—conventional system; Org_M-organic cultivation system with sheep manure; Org_C_-organic cultivation system with sheep manure compost and compost tea ( $n=5$, per cropping system).

The PCoAs of the bacterial (Figure 4A) and fungal (Figure 4B) microbial communities showed significant differences among the different cropping systems, which were confirmed by PERMANOVA ( $\mathrm{F}=1.792, \mathrm{P}=0.006 ; \mathrm{F}=7.649$, and $\mathrm{P}=0.001$ respectively). 


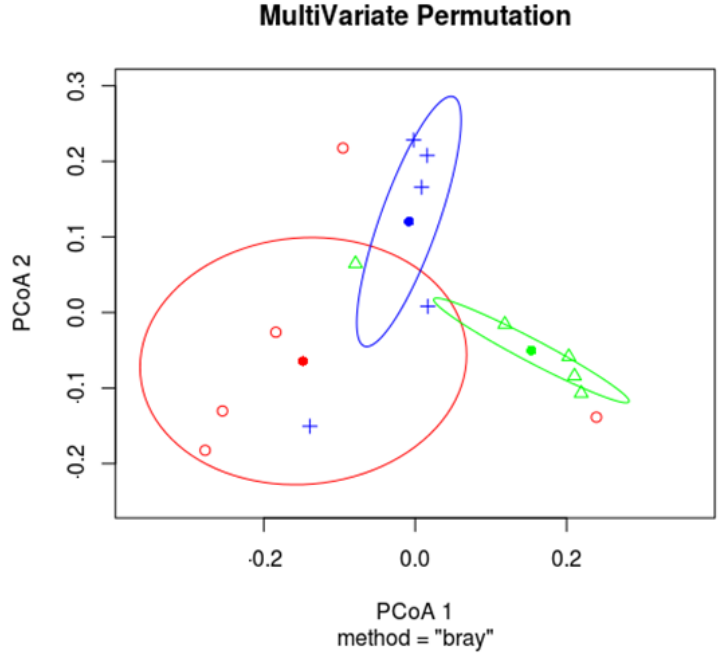

(A)

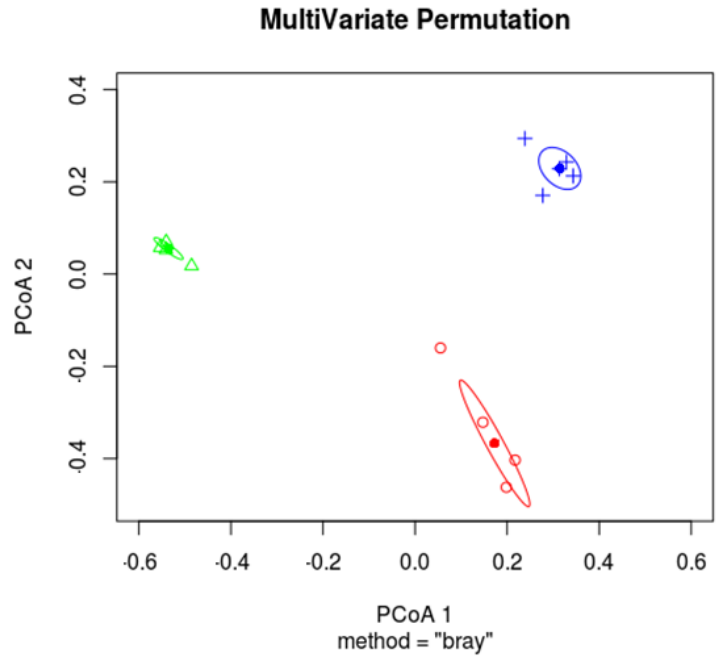

(B)

Figure 4. Principal coordinate analysis (PCoA) of the (A) bacterial and (B) fungal community structures between the three cropping systems. Different colors and shapes represent the different points of the group-Conv is indicated by red circles, Org_C by green triangles, and Org_M by blue crosses. PCoA displays the group centroids and dispersions. Convconventional system; Org_C_-organic cultivation with manure compost and tea compost; Org_M—organic cultivation with manure $(n=5$, per cropping system).

\subsection{Effects of Different Cropping Systems on Bacterial and Fungal Community Composition}

The main bacterial and fungal taxa found in the different cropping systems are shown in Figures 5-7. The most dominant phyla under the different cropping systems were Proteobacteria (42\% in average), Actinobacteria (16\%), Bacteriodetes $(12 \%)$, and Acidobacteria (7\%; Figure 5A and Table S3). No significant differences were found among the three cropping systems when using Bray-Curtis dissimilarity at a phylum level (PERMANOVA: $\mathrm{F}=0.821 ; \mathrm{P}=0.562)$. SIMPER pairwise comparisons showed that the Proteobacteria, Gemmatimonadetes, Bacteriodetes, and Actinobacteria accounted for $75 \%$ of the overall dissimilarities between Conv and Org_M or Org_C.

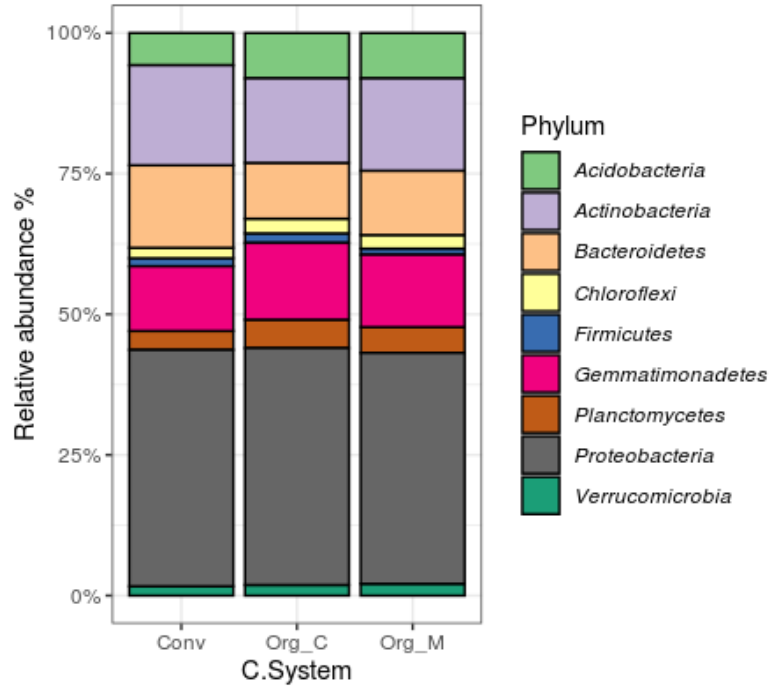

(A)

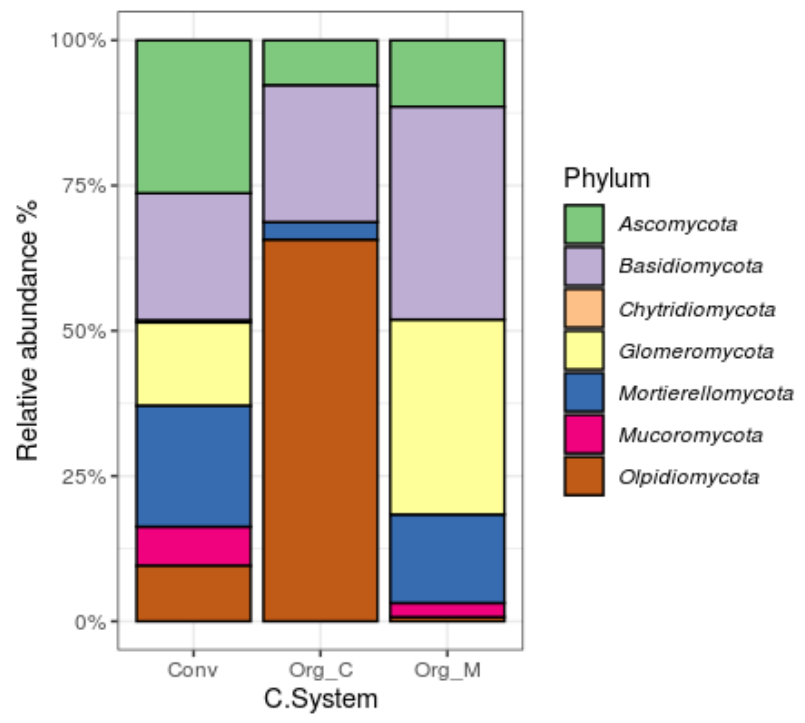

(B)

Figure 5. Relative abundance ( $>1 \%$ ) of (A) bacterial and (B) fungal phylum of the three cropping systems. Bar values are mean $\pm \mathrm{SD}(n=5)$. Conv—conventional system; Org_C_-organic cultivation with manure compost and tea compost; Org_M-organic cultivation with manure. 


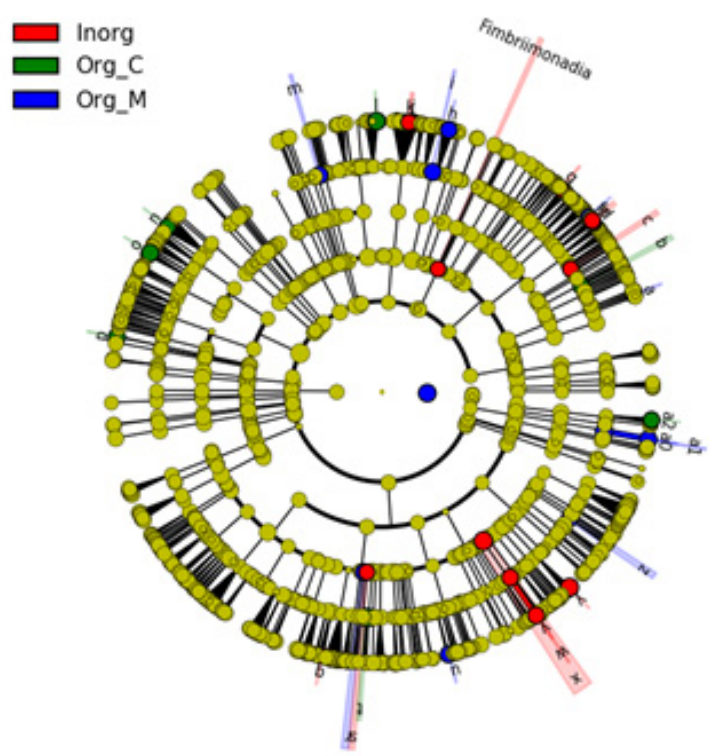

(A)

$$
\begin{aligned}
& \text { Inorg } \\
& \text { Org_C } \\
& \text { Org_M }
\end{aligned}
$$$$
\text { Org_M }
$$

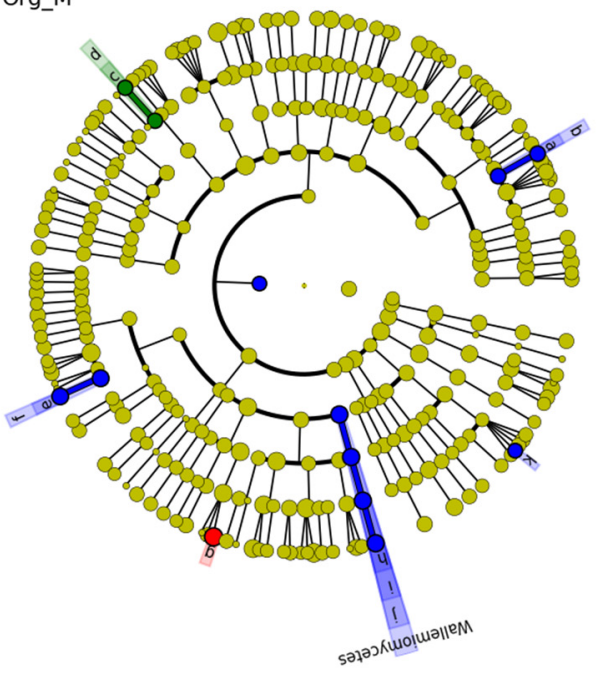

(B)
a:Aciditerrimongs

b: Geodermatoohilacege

Cellulomongdaces

d. Glutamicibacter

d: Glutamicibacter

e: Nesterenkonia

f: Isoptericola.

g: Saccharothrix

h: Nibribacter
i: CytophagaceaeBacterioidetes

() Galbibacter

k: Gramella

I: Dinghuibacter

m: OPB56

$\square$ n: Piscibacillus

a. Planifilumcompostbacterium

p: Turicibacter

a: Limnobacter

r: Methylophilales

s: Neisseriales

t: Gallionellscege

u: Haliangiumsoilbacterium

v. Pseudoalteromongs

wi Pseudoglteromongdgcese

x:Alteromonadales

y: Pantoes

- 2 Moraxellacese

- 2i Moraxellaceae

al: Chthoniobacter

a2: Roseibacillus 


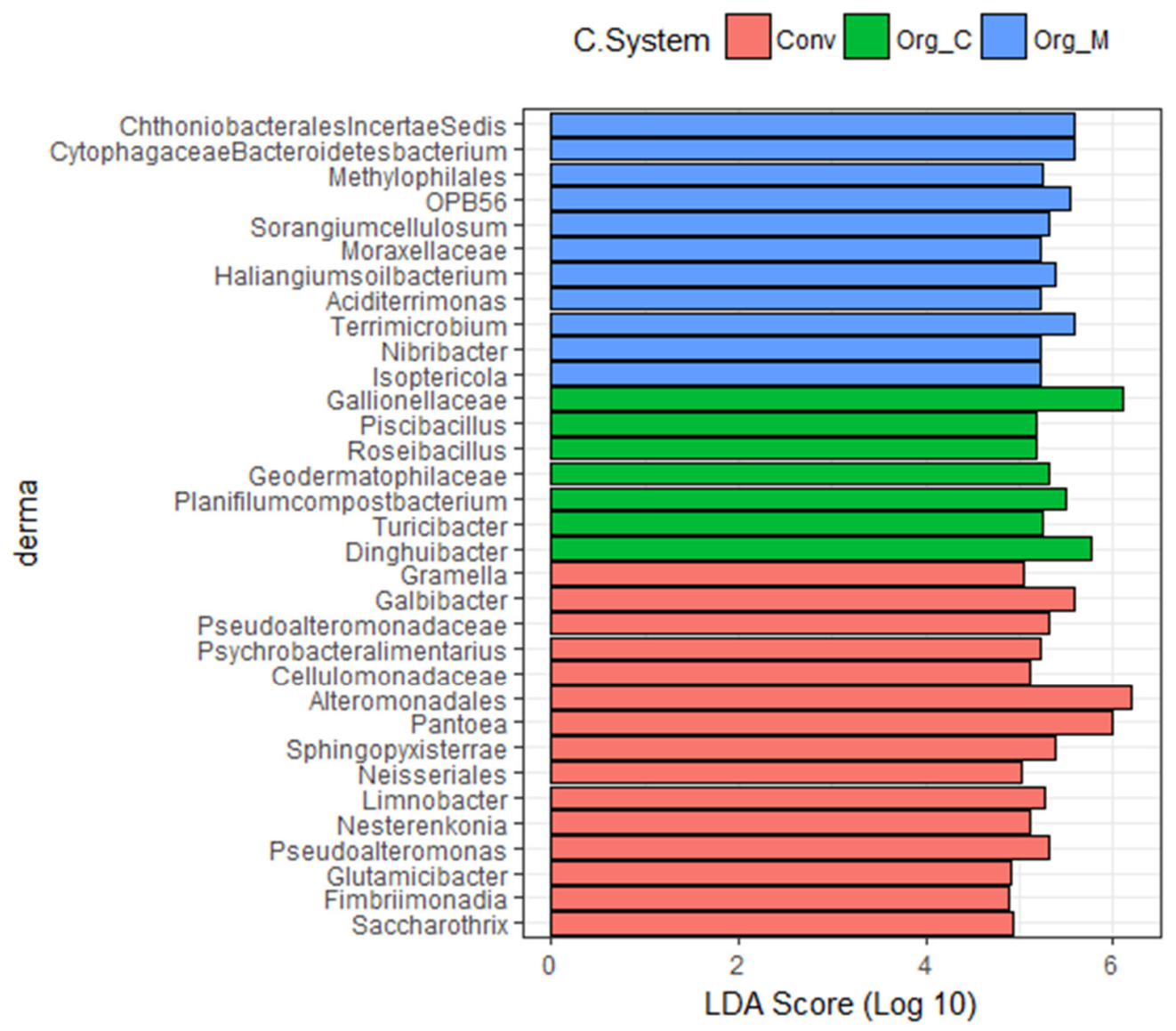

(A)

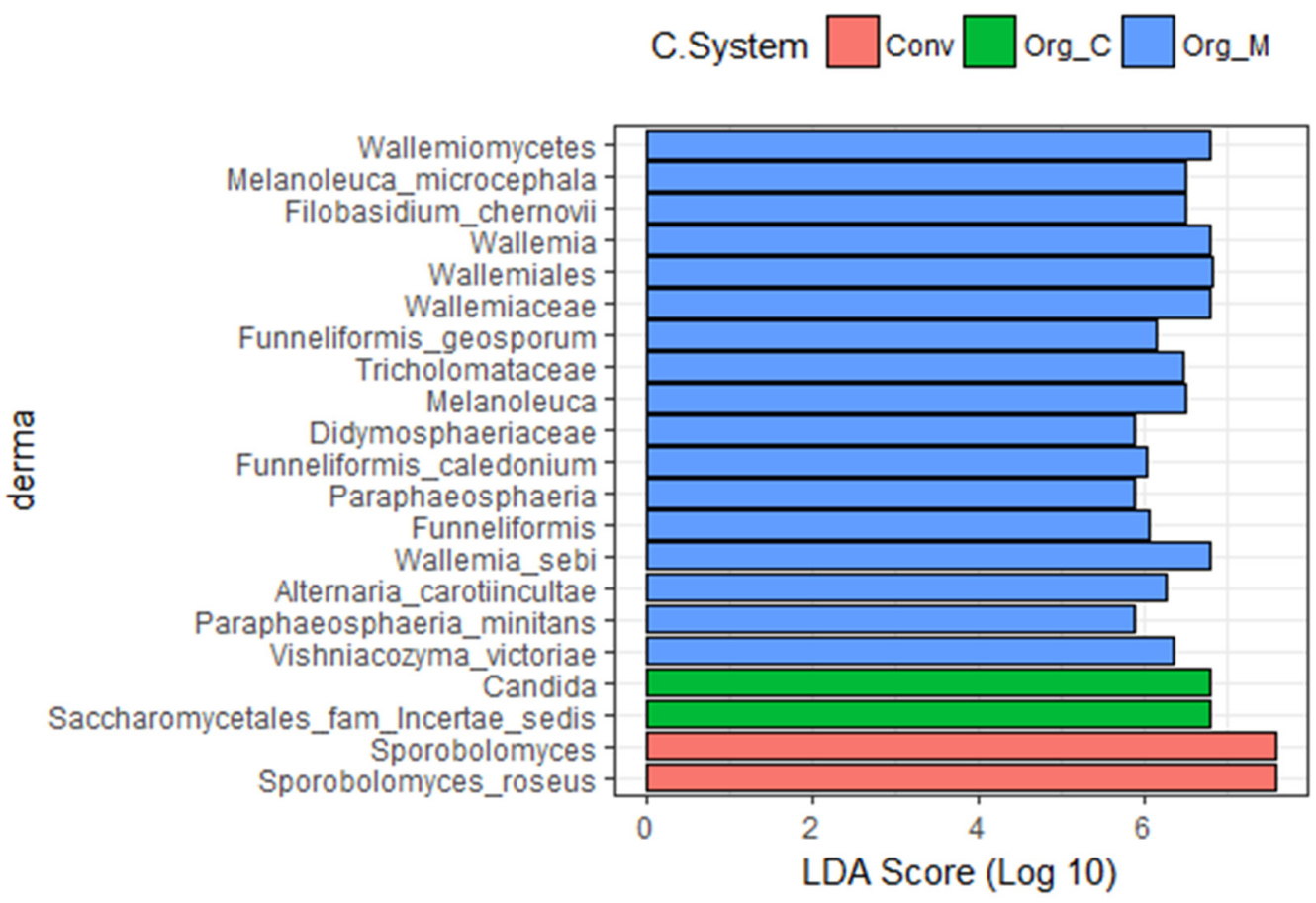

(B)

Figure 7. Linear discriminant analysis effect size (LEfSe) analysis showing (A) bacterial and (B) fungal microbiota changes between the three cropping systems. Conv—conventional system; Org_M-organic cultivation with manure; Org_Corganic cultivation with manure compost and tea compost ( $n=5$, per cropping system). 
The most abundant fungal phylum was Basidiomycota $(27 \%$ on average), followed by Olpidiomycota (25\%), Ascomycota (15\%), Glomeromycota (15\%), and Mortierellomycota (13\%; Figure 5B and Table S4). Significant differences were found between the three cropping systems (PERMANOVA: $\mathrm{F}=4.83, \mathrm{P}=0.003$ ). The highest relative abundance of Basidomycota and Glomeromycota was observed in Org_M, while Olpidiomycota showed the highest abundance in Org_C. The highest abundance for Ascomycota and Mortierellomycota was found for the Conv system, followed by Org_M and Org_C (Table S4). SIMPER showed that Glomeromycota, Basidiomycota, and Ascomycota accounted for 73\% of the dissimilarities between Conv and Org_M, while Olpidiomycota, Basidiomycota, and Ascomycota accounted for $74 \%$ of the dissimilarities between Conv and Org_C.

LEfSe was conducted to identify the taxa that display significant differences among the three cropping systems. For bacteria, the Conv system had fifteen differential taxa, while Org_C had seven and Org_M had eleven (Figures 6A and 7A). At the genus level, Nesterenkonia (Actinobacteria); Galbibacter and Gramella (Bacteroidetes); and Limnobacter, Pseudoalteromonas, and Pantoe (Proteobacteria) were the most differential taxa in the Conv system. The genomic features in the organic systems identified the genera Aciditerrimonas and Isoptericola (Actinobacteria), Nibribacter (Bacteroidete), Haliangium (Proteobacteria), and Terrimicrobium (Verrucomicrobia) as important taxonomic contributors for Org_M, and the genera Dinghuibacter and Turibacter (Bacteroidete), Piscibacillus and Planifilium (Firmicutes), and Roseibacillus (Verrucomicrobia) as important taxonomic contributors for Org_C (Figures 6A and 7A). For fungi, the Conv system showed two differential taxa; among the organic systems, Org_C showed two differential taxa and Org_M seventeen (Figures 6B and 7B). The genus Sporobolomyces (Basidomycota) was the only genomic feature in the Conv system. For the organic systems, we found the genera Wallemiales (Basidiomycota), Funneliformis (Glomerales), Melanoleuca (Basidiomycota), and Alternaria and Paraphaeosphaera (Ascomycota) in Org_M, and the genus Candida (Ascomycota) in Org_C.

\subsection{The Relationship between the Microbial Community and Soil Properties}

A nonmetric multidimensional scaling (NMDS) was assayed for establishing the relationship between bacterial and fungal communities and the significant soil parameters. For bacteria, $\mathrm{TOC}, \mathrm{TN}, \mathrm{NH}_{4}{ }^{+}, \mathrm{Mg}$, and, $\mathrm{B}$ were the soil properties that showed a significant effect on the bacterial community composition (Table S5). However, for fungi, no significant correlation was found (Table S6).

A Spearman correlation analysis between the soil properties and bacterial and fungal genera showed a significant correlation between Nesterenkonia and total pesticide $\left(0.68^{* *}\right)$; Gramella and total pesticide $(0.52 *)$; Pseudoalteromonas and Pantoe with total pesticide $\left(0.56{ }^{*}\right)$; Sporobolomyces and total pesticide (0.80); Planifilium, Dinghuibacter, Turicibacter, Piscibacillus, Melanoleuca, Filobasidium, and Candida showed a high correlation with $\mathrm{NH}_{4}{ }^{+}$ $\left(0.60^{*}, 0.66^{* *}, 0.59^{*}, 0.74^{* *},-0.77^{* *},-0.76^{* *}\right.$, and $0.70^{* *}$, respectively); Aciditerrimonas, Roseibacillus, and Nibribacter showed a high correlation with TOC $(0.82 * * * 0.74 * *$, and $-0.65^{* *}$, respectively) and Aciditerrimonas with total nitrogen $\left(0.64^{* *}\right)$; Terrimicrobium with $\mathrm{NH}_{4}{ }^{*}\left(-0.58^{*}\right)$; and Wallemia with both pathogens Alternaria spp. $\left(-0.77^{* *}\right)$ and Fusarium oxysporum $\left(-0.56^{* *}\right)$ and with $\mathrm{NH}_{4}^{*}\left(-0.66^{*}\right)$.

\section{Discussion}

Organic and conventional farming are nowadays defined based on differences regarding fertilization, plant cultivation, and soil management. Our three cropping systems have the same soil type and climate, are located in close proximity, and have undergone the same crop rotation. Therefore, it is likely that the differences observed in soil properties and microbial community are probably due to crop systems. The results highlight that once organic systems are stabilized over time, production can be as high as that of conventional systems if the soil and crops are effectively managed and nutrient availability is ensured [52,53]. Differences among the cropping systems related to soil properties indicated that the higher organic carbon content in Org_C may have contributed to the 
slightly lower $\mathrm{pH}$ in soil compared with Org_M, owing to the greater presence of organic acids $[54,55]$. The addition of compost instead of manure may therefore provide positive effects in basic soils, contributing to a decrease in $\mathrm{pH}$ and making nutrients more available. Meanwhile, the highest $\mathrm{pH}$ showed by Org_M can be explained by the buffering capacity from bicarbonates and organic acids in the manure, with no addition of nitric acid, as used in Conv to decrease the $\mathrm{pH}$ [56]. On the other hand, the higher $\mathrm{NO}_{3}{ }^{-}$levels observed in the Conv system were probably due to intensive chemical fertilizer and pesticide use, and the addition of nitric acid in fertigation $[57,58]$.

It is interesting to highlight that soil parameters such as TOC and some nutrients like $\mathrm{TN}, \mathrm{Mg}$, and B were associated with changes in the soil bacterial community, as observed by Yang et al. [59] and Zhang et al. [60]. It is well known that compost enhances carbon and nitrogen in soils, thus changing the microbial communities [61]. In addition, Vera et al. [62] observed that the boron content in the soil was a determinant property explaining the changes in the bacterial community in agricultural soil. According to Vera et al. [63], organic matter had a key influence on the potential microbial action with high boron doses, and our findings could support that influence, as some key microorganisms from soil organic cropping system had a high correlation with boron.

Although the bacterial community structure changed in response to the different cropping systems, this was not associated with significant variations in alpha diversity [64]. It was contrary to the lower values expected in conventional systems due to the adverse effects of agrochemicals [65-67]. Moreover, a significantly higher fungal diversity was observed in the Conv system, probably due to the increase in nutrient availability, as previously observed by Geisseler and Scow [68] and Leff et al. [69], and the breakage of fungal hyphae by tillage [70]. Legacy effects of cropping systems occur in specific microbial groups and cannot be resolved by determining the diversity of the entire microbial community, as shifts in some groups might be compensated for shifts in others [71].

Most importantly, our results showed that there are different effects from the various cropping systems on the soil microbial community structure. Indeed, the impact of the cropping system is considered to be stronger than any potential spatiotemporal variations [72]. The effect of the different cropping systems was not reflected in the dominant bacterial phyla, contrary to that observed by Lupatini et al. [71] or Moreno-Espíndola et al. [73]. Hartman et al. [72] observed that differences in the bacterial community between organically farmed and conventionally managed soils under integrated fertilization were smaller. Contrary to the bacterial community, the fungal microbial composition did change significantly among the three cropping systems. The relative abundance of Ascomycota and Mortierellomycota markedly increased in response to the fertilizer treatments. Ascomycota and Mortierellomycota rapidly metabolize rhizodeposited organic matter in rhizosphere soil, so their abundances are stimulated by nutrient substance [74].

Hence, fertilizer management may result in suitable circumstances for phyla that obtain sufficient levels of $\mathrm{C}, \mathrm{N}$, and $\mathrm{P}$ from the top soil [75].

Basidiomycota and Glomeromycota had the greatest dissimilarity in Org_M compared with Conv. Previous studies showed that Basidiomycota was increased in soils with manure as it provides an appropriate environment for Basidiomycota [76]. However, chemical fertilizer can cause the loss of that environment and can hinder the development of this phyla [76]. A high abundance of Glomeromycota in Org_M can form arbuscular mycorrhiza with plants and absorb nutrients directly, particularly P uptake through the plant roots [77], promoting plant growth, and enhance plant resistance to various pathogens [78], so it could be possible that its high abundance is related to the lower abundance of both pathogens, Fusarium oxysporum and Alternaria spp., and the nearly non-existant abundance of Olpidyomicota (Olpidium). Contrarily, Olpidyomicota was more abundant in Org_C, in which no Glomeromycota was found. However, the possible infection of plants by some pathogens species of Olpidyomicota (Olpidium) in subsequent crops could be determined to cause disease on some of them, along with certain environmental factors [79]. Furthermore, Carini et al. [80] discovered that up to $50 \%$ of the microbial nucleic acid sequences in 
environmental samples could correspond to dead and inactive biomass. So, quantification by RNA would provide a more meaningful assessment of cellular viability and plant infection [79].

The presence of several differentially taxa among cropping systems provides information on soil microbiota responses to different agricultural management practices [81]. According to the LEfSe analysis, the long-term application of pesticides in the Conv system favored the greater existence of microorganisms associated with the pesticides, such as Nesterenkonia, Galbibacter, Gramella, Limnobacter, Pseudoalteromonas, Pantoe, and Sporobolomyces. Agrochemicals have the potential to inhibit or eliminate certain groups of microbes and select members adapted to or able to grow under conventional farming practices [82]. Pantoea comprises many versatile species with different functions, like the degradation of herbicides and other toxic compounds [83]. Some Pseudoalteromonas strains can produce bioactive compounds [84], and Sporobolomyces is a yeast capable of pesticide degradation [60]. Under Org_C, Turicibacter, Dinghiubacter, Planifilium, Roseibacillus, Piscibacillus, and Candida were more abundant and were positively correlated with ammonium, indicating that the presence of ammonium could favor the presence of these genera. Previous studies also reported that Turicibacter are abundant in soil with manure application and a high total organic carbon [85]. Regarding to Candida, it is important to point out that it is a saprotrophic fungi that sometimes come from compost, and may cause an opportunistic hazard to human health [86].

Org_M-related genera were Aciditerrimonas, Isoptericola, Nibribacter, Haliangium, Terrimicrobium, Funneliformis, Wallemia, Melanoleuca, and Filobasidium. Aciditerrimonas is related to ferrous-ferric redox [87], and showed a correlation with TOC and $\mathrm{NH}_{4}{ }^{+}$. Haliangium is a genus in which some species are producers of haliangicins, known as antifungal compounds [88], or Wallemiales, which have been observed in organic cultivations in other studies [7], and have shown a strong negative correlation with Alternaria spp. and Fusarium Oxysporum. This suggests that an increase in this genus could favor a decrease in some phytopathogens [89], as we observed in this cropping system.

\section{Practical Implications of This Study}

In this study, the impacts of two types of long-term organic farming and one conventional farming system on the soil chemical properties and microbial communities are highlighted. This study highly recommends organic farming, principally the one where compost was used as an organic amendment (Org_C), where no differences were observed on crop yield with the other systems and it had a stable system with a high total organic carbon and nutrients, as well as a change in the bacterial and fungal communities. In addition to the environmental and human benefits of this type of farming system, further studies should further examine the possible mechanisms behind microbial community changes related to specific biogeochemical cycles, as well as the functional approach and inter-connection between microbial communities.

\section{Conclusions}

This work showed that properly long-term organic systems can contribute to maintaining high-yielding and stable crops when compared to the conventional system. In particular, it is noticeable that Org_C showed a change in bacterial community associated with an improvement in the soil carbon and nutrient content that was not found with Org_M. Analyses showed that fungal communities were more sensitive to cropping systems than bacteria because of the changes on a phylum level, while bacteria changes were more apparent on a specific taxonomy level. In addition, the LEfSe analysis revealed different microorganisms associated with each of the studied cropping systems. In particular, for the Conv system, the analysis demonstrated the presence of microorganisms associated with pesticide, while Org_C and Org_M microorganisms were associated with organic matter decomposition with different putative functions that, in some cases, could reduce soil borne pathogens. 
Supplementary Materials: The following are available online at https: / www.mdpi.com/article/ 10.3390/agriculture11050445/s1, Figure S1: Rarefaction curves for the bacterial and fungal soil sequences, Table S1: Characteristics of organic amedments, Table S2: Diversity index for the bacterial and fungal community, Table S3: Relative abundance of most abundant bacterial phyla, Table S4: Relative abundance of most abundant fungal phyla, Table S5: NMDS results between bacterial community and the significant properties, Table S6: NMDS results between fungal community and the significant properties.

Author Contributions: Conceptualization, M.R., J.A.P., J.-M.V. and J.C.; methodology, J.C., J.-M.V., M.R., O.Ö., M.E.-C., L.O. and L.C.; validation, M.R., J.A.P. and J.-M.V.; formal analysis, J.C. and J.-M.V.; investigation, R.Z., M.R. and J.A.P.; resources, V.S.-N. and O.Ö.; data curation, J.C. and M.R.; writing—original draft preparation, J.C.; writing—review and editing, M.R., J.A.P., J.-M.V. and J.C.; data visualization, J.C.; supervision, J.-M.V., M.R. and J.A.P.; project administration, M.R.; funding acquisition, M.R., J.A.P. and R.Z. All authors have read and agreed to the published version of the manuscript.

Funding: This research was funded by the European Union (program H2020, grant number 728003).

Institutional Review Board Statement: Not applicable.

Informed Consent Statement: Not applicable.

Data Availability Statement: The data presented in this study are available on https://zenodo.org/ record/4763091\#.YJ7D3aGxVPY (accessed on 14 May 2021).

Acknowledgments: Raúl Zornoza acknowledges the financial support received from the Spanish Ministry of Science, Innovation and Universities through the "Ramón y Cajal" Program (RYC-201518758). We would like to thank Ansley Evans for providing English corrections.

Conflicts of Interest: The authors declare no conflict of interest.

\section{References}

1. ITPS FAO. Food Agric. In Status of the World's Soil Resources (SWSR) Main Report; Organ. United Nations Intergov. Tech. Panel Soils: Rome, Italy, 2015.

2. Le Campion, A.; Oury, F.-X.; Heumez, E.; Rolland, B. Conventional versus organic farming systems: Dissecting comparisons to improve cereal organic breeding strategies. Org. Agric. 2020, 10, 63-74. [CrossRef]

3. Bonou-zin, R.D.C.; Allali, K.; Fadlaoui, A. Environmental Efficiency of Organic and Conventional Cotton in Benin. Sustainability 2019, 11, 3044. [CrossRef]

4. Tully, K.L.; McAskill, C. Promoting soil health in organically managed systems: A review. Org. Agric. 2020, 10, 339-358. [CrossRef]

5. Eurostat. Organic Farming Statistics. Available online: http://ec.europa.eu/eurostat/statistics-explained/index.php/Organic_ farming_statistics (accessed on 15 January 2019).

6. De Ponti, T.; Rijk, B.; Van Ittersum, M.K. The crop yield gap between organic and conventional agriculture. Agric. Syst. 2012, 108, 1-9. [CrossRef]

7. Bonanomi, G.; De Filippis, F.; Cesarano, G.; La Storia, A.; Ercolini, D.; Scala, F. Organic farming induces changes in soil microbiota that affect agro-ecosystem functions. Soil Biol. Biochem. 2016, 103, 327-336. [CrossRef]

8. Luo, G.; Li, L.; Friman, V.-P.; Guo, J.; Guo, S.; Shen, Q.; Ling, N. Organic amendments increase crop yields by improving microbe-mediated soil functioning of agroecosystems: A meta-analysis. Soil Biol. Biochem. 2018, 124, 105-115. [CrossRef]

9. Dangi, S.R.; Bañuelos, G.; Buyer, J.S.; Hanson, B.; Gerik, J. Microbial community biomass and structure in saline and non-saline soils associated with salt-and boron-tolerant poplar clones grown for the phytoremediation of selenium. Int. J. Phytoremediat. 2018, 20, 129-137. [CrossRef]

10. Nannipieri, P.; Ascher, J.; Ceccherini, M.T.; Landi, L.; Pietramellara, G.; Renella, G. Microbial diversity and soil functions. Eur. J Soil Sci. 2017, 68, 12-26. [CrossRef]

11. Schrama, M.; De Haan, J.J.; Kroonen, M.; Verstegen, H.; Van der Putten, W.H. Crop yield gap and stability in organic and conventional farming systems. Agric. Ecosyst. Environ. 2018, 256, 123-130. [CrossRef]

12. Wagner, S.; Cattle, S.R.; Scholten, T. Soil-aggregate formation as influenced by clay content and organic-matter amendment. J. Plant Nutr. Soil Sci. 2007, 170, 173-180. [CrossRef]

13. Chaudhry, V.; Rehman, A.; Mishra, A.; Chauhan, P.S.; Nautiyal, C.S. Changes in bacterial community structure of agricultural land due to long-term organic and chemical amendments. Microb. Ecol. 2012, 64, 450-460. [CrossRef] [PubMed]

14. Reilly, K.; Cullen, E.; Lola-Luz, T.; Stone, D.; Valverde, J.; Gaffney, M.; Brunton, N.; Grant, J.; Griffiths, B.S. Effect of organic, conventional and mixed cultivation practices on soil microbial community structure and nematode abundance in a cultivated onion crop. J. Sci. Food Agric. 2013, 93, 3700-3709. [CrossRef] 
15. Gonthier, D.J.; Ennis, K.K.; Farinas, S.; Hsieh, H.-Y.; Iverson, A.L.; Batáry, P.; Rudolphi, J.; Tscharntke, T.; Cardinale, B.J.; Perfecto, I. Biodiversity conservation in agriculture requires a multi-scale approach. Proc. R. Soc. B Biol. Sci. 2014, 281, 20141358. [CrossRef] [PubMed]

16. Bell, L.W.; Sparling, B.; Tenuta, M.; Entz, M.H. Soil profile carbon and nutrient stocks under long-term conventional and organic crop and alfalfa-crop rotations and re-established grassland. Agric. Ecosyst. Environ. 2012, 158, 156-163. [CrossRef]

17. Krishnaraj, P.U.; Sabale, S.N. Effect of organic and inorganic fertilization on soil bacterial diversity associated with sole crop (Pigeon pea) and crop rotation (Green gram-Sorghum). J. Pharmacogn. Phytochem. 2019, 8, 577-581.

18. IUSS Working Group WRB. World Reference Base for Soil Resources 2014, Update 2015, International Soil Classification System for Naming Soils and Creating Legends for Soil Maps; In World Soil Resources Reports; FAO: Rome, Italy, 2015.

19. ISO HRN. Soil Quality—Determination of Dry Bulk Density; Croat Stand Institute: Zagreb, Croat, 2017.

20. De Angelis, M. The Beginning of History: Value Struggles and Global Capital; Pluto Press: London, UK, 2007 ; ISBN 0745320368.

21. ISO. Soil Quality: Determination of the Potential Cation Exchange Capacity and Exchangeable Cations Using Barium Chloride Solution Buffered at PH; ISO 13536:1995. Available online: https://www.iso.org/standard/22180.html (accessed on 5 January 2021).

22. Van Genuchten, M.T. A closed-form equation for predicting the hydraulic conductivity of unsaturated soils. Soil Sci. Soc. Am. J. 1980, 44, 892-898. [CrossRef]

23. UGT. UGT Products. Soil Science; UGT: Müncheberg, Germany, 2018. Available online: http://www.ugt-online.de/en/products/ soil-science/ (accessed on 10 March 2017).

24. Cambardella, C.A.; Elliott, E.T. Particulate soil organic-matter changes across a grassland cultivation sequence. Soil Sci. Soc. Am. J. 1992, 56, 777-783. [CrossRef]

25. Chen, H.; Hou, R.; Gong, Y.; Li, H.; Fan, M.; Kuzyakov, Y. Effects of 11 years of conservation tillage on soil organic matter fractions in wheat monoculture in Loess Plateau of China. Soil Tillage Res. 2009, 106, 85-94. [CrossRef]

26. Keeney, D.R.; Nelson, D.W. Nitrogen-Inorganic forms. Methods Soil Anal. Part 2 Chem. Microbiol. Prop. 1983, 9, 643-698.

27. Kandeler, E.; Gerber, H. Short-term assay of soil urease activity using colorimetric determination of ammonium. Biol. Fertil. Soils 1988, 6, 68-72. [CrossRef]

28. Olsen, S.R. Estimation of Available Phosphorus in Soils by Extraction with Sodium Bicarbonate; U.S. Department of Agriculture: Washington, DC, USA, 1954.

29. Kabata-Pendias, A. Trace Elements in Soils and Plants; CRC Press: Boca Raton, FL, USA, 2000; ISBN 1420039903.

30. Reichman, S.M. The Responses of Plants to Metal Toxicity: A Review Forusing on Copper, Manganese E Zinc; Australian Minerals \& Energy Environment Foundation Melbourne: Melbourne, Australia, 2002; ISBN 187620513X.

31. Porta Casanellas, J.; López Acevedo Requerin, M.; Rodríguez Ochoa, R. Técnicas y Experimentos en Edafología; Romanyá/Valls: Capellades, Spain, 1986; ISBN 846004341X.

32. Anastassiades, M.; Lehotay, S.J.; Štajnbaher, D.; Schenck, F.J. Fast and easy multiresidue method employing acetonitrile extraction/partitioning and "dispersive solid-phase extraction" for the determination of pesticide residues in produce. J. AOAC Int. 2003, 86, 412-431. [CrossRef] [PubMed]

33. Taskin, B.; Gozen, A.G.; Duran, M. Selective quantification of viable Escherichia coli bacteria in biosolids by quantitative PCR with propidium monoazide modification. Appl. Environ. Microbiol. 2011, 77, 4329-4335. [CrossRef] [PubMed]

34. Smith, D.P.; Peay, K.G. Sequence depth, not PCR replication, improves ecological inference from next generation DNA sequencing. PLoS ONE 2014, 9, e90234. [CrossRef] [PubMed]

35. Caporaso, J.G.; Lauber, C.L.; Walters, W.A.; Berg-Lyons, D.; Huntley, J.; Fierer, N.; Owens, S.M.; Betley, J.; Fraser, L.; Bauer, M. Ultra-high-throughput microbial community analysis on the Illumina HiSeq and MiSeq platforms. ISME J. 2012, 6, $1621-1624$. [CrossRef]

36. Bragg, L.; Stone, G.; Imelfort, M.; Hugenholtz, P.; Tyson, G.W. Fast, accurate error-correction of amplicon pyrosequences using Acacia. Nat. Methods 2012, 9, 425. [CrossRef]

37. Caporaso, J.G.; Kuczynski, J.; Stombaugh, J.; Bittinger, K.; Bushman, F.D.; Costello, E.K.; Fierer, N.; Pena, A.G.; Goodrich, J.K.; Gordon, J.I. QIIME allows analysis of high-throughput community sequencing data. Nat. Methods 2010, 7, 335. [CrossRef] [PubMed]

38. Comeau, A.M.; Douglas, G.M.; Langille, M.G.I. Microbiome helper: A custom and streamlined workflow for microbiome research. MSystems 2017, 2. [CrossRef] [PubMed]

39. Rognes, T.; Flouri, T.; Nichols, B.; Quince, C.; Mahé, F. VSEARCH: A versatile open source tool for metagenomics. PeerJ 2016, 4, e2584. [CrossRef]

40. Cole, J.R.; Wang, Q.; Fish, J.A.; Chai, B.; McGarrell, D.M.; Sun, Y.; Brown, C.T.; Porras-Alfaro, A.; Kuske, C.R.; Tiedje, J.M. Ribosomal Database Project: Data and tools for high throughput rRNA analysis. Nucleic Acids Res. 2014, 42, D633-D642. [CrossRef]

41. Bolger, A.M.; Lohse, M.; Usadel, B. Trimmomatic: A flexible trimmer for Illumina sequence data. Bioinformatics 2014, 30, 2114-2120. [CrossRef]

42. Zhang, J.; Kobert, K.; Flouri, T.; Stamatakis, A. PEAR: A fast and accurate Illumina Paired-End reAd mergeR. Bioinformatics 2014, 30, 614-620. [CrossRef] [PubMed]

43. Kõljalg, U.; Nilsson, R.H.; Abarenkov, K.; Tedersoo, L.; Taylor, A.F.S.; Bahram, M.; Bates, S.T.; Bruns, T.D.; Bengtsson-Palme, J.; Callaghan, T.M. Towards a unified paradigm for sequence-based identification of fungi. Mol. Ecol. 2013, 22, 5271-5277. [CrossRef] 
44. R Core Team. R: A Language and Environment for Statistical Computing (Version 3.5.3); R Core Team: Boston, MA, USA, 2019.

45. Ogle, D.H. FSA: Fisheries Stock Analysis. R Packag. Version 0.8.30. Available online: https://github.com/droglenc/FSA (accessed on 5 January 2019).

46. Lê, S.; Josse, J.; Husson, F. FactoMineR: An R package for multivariate analysis. J. Stat. Softw. 2008, 25, 35095. [CrossRef]

47. Kassambara, A.; Mundt, F. Factoextra: Extract and visualize the results of multivariate data analyses. $R$ Package Version 2020, 1 , 337-354.

48. Hsieh, T.C.; Ma, K.H.; Chao, A. iNEXT: An R package for rarefaction and extrapolation of species diversity (Hill numbers). Methods Ecol. Evol. 2016, 7, 1451-1456. [CrossRef]

49. Oksanen, J.; Blanchet, F.G.; Kindt, R.; Legendre, P.; O’hara, R.B.; Simpson, G.L.; Solymos, P.; Stevens, M.H.H.; Wagner, H. Vegan Community Ecology Package. R Package Version 1.17-4. Available online: http//CRAN.R-project.org/package=vegan2010 (accessed on 14 June 2019).

50. Segata, N.; Izard, J.; Waldron, L.; Gevers, D.; Miropolsky, L.; Garrett, W.S.; Huttenhower, C. Metagenomic biomarker discovery and explanation. Genome Biol. 2011, 12, R60. [CrossRef]

51. Afgan, E.; Baker, D.; Batut, B.; Van Den Beek, M.; Bouvier, D.; Čech, M.; Chilton, J.; Clements, D.; Coraor, N.; Grüning, B.A. The Galaxy platform for accessible, reproducible and collaborative biomedical analyses: 2018 update. Nucleic Acids Res. 2018, 46, W537-W544. [CrossRef]

52. Jannoura, R.; Joergensen, R.G.; Bruns, C. Organic fertilizer effects on growth, crop yield, and soil microbial biomass indices in sole and intercropped peas and oats under organic farming conditions. Eur. J. Agron. 2014, 52, 259-270. [CrossRef]

53. Cai, A.; Xu, M.; Wang, B.; Zhang, W.; Liang, G.; Hou, E.; Luo, Y. Manure acts as a better fertilizer for increasing crop yields than synthetic fertilizer does by improving soil fertility. Soil Tillage Res. 2019, 189, 168-175. [CrossRef]

54. Irshad, M.; Eneji, A.E.; Hussain, Z.; Ashraf, M. Chemical characterization of fresh and composted livestock manures. J. Soil Sci. Plant Nutr. 2013, 13, 115-121. [CrossRef]

55. Adeleke, R.; Nwangburuka, C.; Oboirien, B. Origins, roles and fate of organic acids in soils: A review. S. Afr. J. Bot. 2017, 108, 393-406. [CrossRef]

56. Ge, G.; Li, Z.; Fan, F.; Chu, G.; Hou, Z.; Liang, Y. Soil biological activity and their seasonal variations in response to long-term application of organic and inorganic fertilizers. Plant Soil 2010, 326, 31. [CrossRef]

57. Li, J.; Cooper, J.M.; Li, Y.; Yang, X.; Zhao, B. Soil microbial community structure and function are significantly affected by long-term organic and mineral fertilization regimes in the North China Plain. Appl. Soil Ecol. 2015, 96, 75-87. [CrossRef]

58. Gu, S.; Gruau, G.; Dupas, R.; Rumpel, C.; Creme, A.; Fovet, O.; Gascuel-Odoux, C.; Jeanneau, L.; Humbert, G.; Petitjean, P. Release of dissolved phosphorus from riparian wetlands: Evidence for complex interactions among hydroclimate variability, topography and soil properties. Sci. Total Environ. 2017, 598, 421-431. [CrossRef]

59. Yang, H.; Meng, Y.; Feng, J.; Li, Y.; Zhai, S.; Liu, J. Direct and indirect effects of long-term ditch-buried straw return on soil bacterial community in a rice-wheat rotation system. Land Degrad. Dev. 2020, 31, 851-867. [CrossRef]

60. Zhang, Y.; Li, Q.; Chen, Y.; Dai, Q.; Hu, J. Dynamic change in enzyme activity and bacterial community with long-term rice cultivation in mudflats. Curr. Microbiol. 2019, 76, 361-369. [CrossRef]

61. Liu, X.; Rashti, M.R.; Dougall, A.; Esfandbod, M.; Van Zwieten, L.; Chen, C. Subsoil application of compost improved sugarcane yield through enhanced supply and cycling of soil labile organic carbon and nitrogen in an acidic soil at tropical Australia. Soil Tillage Res. 2018, 180, 73-81. [CrossRef]

62. Vera, A.; Moreno, J.L.; García, C.; Morais, D.; Bastida, F. Boron in soil: The impacts on the biomass, composition and activity of the soil microbial community. Sci. Total Environ. 2019, 685, 564-573. [CrossRef]

63. Vera, A.; Moreno, J.L.; Siles, J.A.; López-Mondejar, R.; Zhou, Y.; Li, Y.; García, C.; Nicolás, E.; Bastida, F. Interactive impacts of boron and organic amendments in plant-soil microbial relationships. J. Hazard. Mater. 2021, 408, 124939. [CrossRef]

64. Buckley, D.H.; Schmidt, T.M. The structure of microbial communities in soil and the lasting impact of cultivation. Microb. Ecol. 2001, 42, 11-21. [CrossRef]

65. Bengtsson, J.; Ahnström, J.; Weibull, A. The effects of organic agriculture on biodiversity and abundance: A meta-analysis. J. Appl. Ecol. 2005, 42, 261-269. [CrossRef]

66. Jackson, C.R.; Vallaire, S.C. Microbial activity and decomposition of fine particulate organic matter in a Louisiana cypress swamp. J. N. Am. Benthol. Soc. 2007, 26, 743-753. [CrossRef]

67. Kremen, C.; Miles, A. Ecosystem services in biologically diversified versus conventional farming systems: Benefits, externalities, and trade-offs. Ecol. Soc. 2012, 17, 40. [CrossRef]

68. Geisseler, D.; Scow, K.M. Long-term effects of mineral fertilizers on soil microorganisms-A review. Soil Biol. Biochem. 2014, 75, 54-63. [CrossRef]

69. Leff, J.W.; Jones, S.E.; Prober, S.M.; Barberán, A.; Borer, E.T.; Firn, J.L.; Harpole, W.S.; Hobbie, S.E.; Hofmockel, K.S.; Knops, J.M.H. Consistent responses of soil microbial communities to elevated nutrient inputs in grasslands across the globe. Proc. Natl. Acad. Sci. USA 2015, 112, 10967-10972. [CrossRef]

70. Allison, V.J.; Miller, R.M.; Jastrow, J.D.; Matamala, R.; Zak, D.R. Changes in soil microbial community structure in a tallgrass prairie chronosequence. Soil Sci. Soc. Am. J. 2005, 69, 1412-1421. [CrossRef]

71. Lupatini, M.; Korthals, G.W.; de Hollander, M.; Janssens, T.K.S.; Kuramae, E.E. Soil microbiome is more heterogeneous in organic than in conventional farming system. Front. Microbiol. 2017, 7, 2064. [CrossRef] 
72. Hartmann, M.; Frey, B.; Mayer, J.; Mäder, P.; Widmer, F. Distinct soil microbial diversity under long-term organic and conventional farming. ISME J. 2015, 9, 1177-1194. [CrossRef]

73. Moreno-Espíndola, I.P.; Ferrara-Guerrero, M.J.; Luna-Guido, M.L.; Ramírez-Villanueva, D.A.; León-Lorenzana, D.; Arit, S.; Gómez-Acata, S.; González-Terreros, E.; Ramírez-Barajas, B.; Navarro-Noya, Y.E. The Bacterial Community Structure and Microbial Activity in a Traditional Organic Milpa Farming System Under Different Soil Moisture Conditions. Front. Microbiol. 2018, 9, 2737. [CrossRef]

74. Bastida, F.; Hernández, T.; Albaladejo, J.; García, C. Phylogenetic and functional changes in the microbial community of long-term restored soils under semiarid climate. Soil Biol. Biochem. 2013, 65, 12-21. [CrossRef]

75. Štursová, M.; Žif̌ćáková, L.; Leigh, M.B.; Burgess, R.; Baldrian, P. Cellulose utilization in forest litter and soil: Identification of bacterial and fungal decomposers. FEMS Microbiol. Ecol. 2012, 80, 735-746. [CrossRef]

76. Tang, H.; Li, C.; Xiao, X.; Shi, L.; Cheng, K.; Wen, L.; Li, W. Effects of short-term manure nitrogen input on soil microbial community structure and diversity in a double-cropping paddy field of southern China. Sci. Rep. 2020, 10, 1-9. [CrossRef]

77. Smith, S.E.; Read, D.J. Mycorrhizal Symbiosis; Academic Press: London, UK, 2010; ISBN 0080559344.

78. Zhu, H.; Liu, X.; Feng, Z.; Yao, Q. Promoting Crop Growth With Symbiotic Microbes in Agro-Ecosystems in Climate Change Era. In New and Future Developments in Microbial Biotechnology and Bioengineering; Elsevier: Amsterdam, The Netherlands, 2019; pp. 31-41.

79. Santísima-Trinidad, A.B.L.; del Mar Montiel-Rozas, M.; Diéz-Rojo, M.Á.; Pascual, J.A.; Ros, M. Impact of foliar fungicides on target and non-target soil microbial communities in cucumber crops. Ecotoxicol. Environ. Saf. 2018, 166, 78-85. [CrossRef]

80. Carini, P.; Marsden, P.J.; Leff, J.W.; Morgan, E.E.; Strickland, M.S.; Fierer, N. Relic DNA is abundant in soil and obscures estimates of soil microbial diversity. Nat. Microbiol. 2016, 2, 242. [CrossRef]

81. Lian, T.; Ma, Q.; Shi, Q.; Cai, Z.; Zhang, Y.; Cheng, Y.; Nian, H. High aluminum stress drives different rhizosphere soil enzyme activities and bacterial community structure between aluminum-tolerant and aluminum-sensitive soybean genotypes. Plant Soil 2019, 440, 409-425. [CrossRef]

82. Stagnari, F.; Perpetuini, G.; Tofalo, R.; Campanelli, G.; Leteo, F.; Della Vella, U.; Schirone, M.; Suzzi, G.; Pisante, M. Long-term impact of farm management and crops on soil microorganisms assessed by combined DGGE and PLFA analyses. Front. Microbiol. 2014, 5, 644. [CrossRef]

83. Walterson, A.M.; Stavrinides, J. Pantoea: Insights into a highly versatile and diverse genus within the Enterobacteriaceae. FEMS Microbiol. Rev. 2015, 39, 968-984. [CrossRef]

84. Offret, C.; Desriac, F.; Le Chevalier, P.; Mounier, J.; Jégou, C.; Fleury, Y. Spotlight on antimicrobial metabolites from the marine bacteria Pseudoalteromonas: Chemodiversity and ecological significance. Mar. Drugs 2016, 14, 129. [CrossRef]

85. Chroňáková, A.; Schloter-Hai, B.; Radl, V.; Endesfelder, D.; Quince, C.; Elhottová, D.; Šimek, M.; Schloter, M. Response of archaeal and bacterial soil communities to changes associated with outdoor cattle overwintering. PLoS ONE 2015, 10, e0135627. [CrossRef]

86. Galitskaya, P.; Biktasheva, L.; Saveliev, A.; Grigoryeva, T.; Boulygina, E.; Selivanovskaya, S. Fungal and bacterial successions in the process of co-composting of organic wastes as revealed by 454 pyrosequencing. PLoS ONE 2017, $12, \mathrm{e} 0186051$.

87. Rosenberg, E.; DeLong, E.F.; Lory, S.; Stackebrandt, E.; Thompson, F. The Prokaryotes: Actinobacteria; Springer: New York, NY, USA, 2014; ISBN 364230138X.

88. Kundim, B.A.; Itou, Y.; Sakagami, Y.; Fudou, R.; Iizuka, T.; Yamanaka, S.; Ojika, M. New haliangicin isomers, potent antifungal metabolites produced by a marine myxobacterium. J. Antibiot. 2003, 56, 630-638. [CrossRef] [PubMed]

89. Guo, Y.; Zhao, S.; Liu, Q.; Wang, H.; Wang, Y. Premliminary investigation of RNase activity and antifungal activity of $\{\backslash$ sl Wallemia sebi\}. Wei Sheng Wu Xue Tong Bao 2006, 33, 30-33. 